\title{
A Face-to-Face Professional Development Model to Enhance Teaching of Online Research Strategies
}

\author{
Fatima E. Terrazas-Arellanes, Carolyn Knox, \\ Lisa A. Strycker, and Emily Walden \\ University of Oregon College of Education, \\ Eugene, Oregon, USA
}

\author{
fatima@uoregon.edu \\ carolynknox.knox@gmail.com \\ lisas@ori.org ewalden@uoregon.edu
}

\begin{abstract}
\end{abstract}
To help students navigate the digital environment, teachers not only need access to the right technology tools but they must also engage in pedagogically sound, high-quality professional development. For teachers, quality professional development can mean the difference between merely using technology tools and creating transformative change in the classroom. For students - especially those with learning disabilities (SWLDs) - having well-prepared teachers can mean the difference between passive listening and active learning. This report discusses implementation and impact of a face-to-face professional development model designed to enhance teachers' implementation of a web-based curriculum (the SOAR Student Toolkit) for teaching online research strategies to all students (both general education students and SWLDs) in the middle school classroom. Fifteen teachers and 446 students participated in this study. Data were gathered from three school-based implementations across two academic years. Results indicate that teachers found that the face-to-face professional development was of high quality $(100 \%)$, the pace and format was appropriate (93\%), and sufficient practice and feedback were provided (100\%). All teachers said the professional development supported their professional growth in providing differentiated instruction for all students and integrating technology into their instruction. About half of the students agreed or strongly agreed that they were very happy with the use of the SOAR Student Toolkit, found it easy to use, believed it helped them learn online research strategies, and thought it was a good way to teach. Most students said they would use the SOAR Student Toolkit for future research projects at least sometimes. Students who learned the SOAR Student Toolkit from trained teachers improved scores an average of 29.2 percentage points on performance-based assessments, from $31.3 \%(\mathrm{SD}=22.1)$ at pretest to $60.5 \%(\mathrm{SD}=23.0)$ at posttest - a statistically

Material published as part of this publication, either on-line or in print, is copyrighted by the Informing Science Institute. Permission to make digital or paper copy of part or all of these works for personal or classroom use is granted without fee provided that the copies are not made or distributed for profit or commercial advantage AND that copies 1) bear this notice in full and 2) give the full citation on the first page. It is permissible to abstract these works so long as credit is given. To copy in all other cases or to republish or to post on a server or to redistribute to lists requires specific permission and payment of a fee. Contact Publisher@,InformingScience.org to request redistribution permission. significant increase $(F(d f=1,857)=$ $468.4, p<.001)$. Gains for SWLDs were similar to improvements for general education students.

Keywords: teacher training, middle school, digital learning, learning disabilities, special education 


\section{Introduction}

Over the past 20 years, the educator's landscape has morphed dramatically. Educational environments have expanded from analog classrooms to widely diverse, digital learning environments. In order to teach students effective strategies for proficient navigation of the online environment, today's teachers must continually engage in high-quality, research-based professional development. For teachers, quality professional development can mean the difference between engaging students in superficial use of technology tools and a deep transformation of how students and teachers interact to compile information that supports a deeper understanding of complex issues. For students, having a teacher who has been well prepared to teach in a digital learning environment can change passive into active learning.

New content standards require that teachers support student mastery of digital tools and Internet research (Common Core State Standards, 2010). These standards apply to all students, including those with historically poorer performance in state assessments, such as students with learning disabilities (SWLDs) and English language learners (National Center for Education Statistics [NCES], 2015). Digital literacy skills are of paramount importance not only for reaching academic benchmarks, but also for achieving college and career readiness. Thus, there is a critical need to develop and test practical professional development models that provide teachers with the tools and skills they need to teach students, including SWLDs and English language learners, how to operate in the virtual environment.

Project S-SOAR (Stepping Up to Strategies for Online Academic Research) was designed to create and test different professional development models to enhance classroom instruction of the nine Strategies for Online Academic Research (SOAR) (Anderson-Inman \& Knox, 2009). Developed from two converging lines of research (Anderson-Inman \& Ditson, 1999; Leu, 2000, 2002), these strategies include starting a web search, improving a web search, choosing three good sites to open, weighing a website, finding information in a website, reading online, recording notes, creating categories, and combining notes in an outline (Knox, Anderson-Inman, TerrazasArellanes, Walden, \& Hildreth, 2015). The overarching goal of the 5-year S-SOAR project, funded by the U.S. Department of Education's Office for Special Education Programs, was to create effective professional development to prepare middle school teachers to use the web-based SOAR Student Toolkit curriculum to teach the nine online research strategies to diverse students in their classrooms. This toolkit offers a step-by-step approach for students to learn the strategiesfeaturing instructional videos, practice exercises, and formative and summative assessments which they may then apply to their own research projects.

The goal of Project S-SOAR is to test and develop effective professional development models that help teachers instruct all students, and especially SWLDs, with the SOAR Student Toolkit. SWLDs comprise more than half of the 2.7 million middle to high school-aged students in the U.S. with disabilities (Office of Educational Technology, 2010). Because SWLDs receive much of their instruction in general education classrooms, it is important that both special education and general education teachers receive professional development that specifically focuses on how to teach in ways that support both of these populations.

The first phase in the S-SOAR project was to develop, implement, and test a face-to-face professional development model for teachers and to prepare teachers to implement the SOAR Student Toolkit in their classrooms with all students but especially with SWLDs. This report presents teacher- and student-level results from the implementation of this S-SOAR face-to-face professional development model. 


\section{S-SOAR Face-to-Face Professional Development Model}

There is evidence that face-to-face professional development can (a) enhance student outcomes when based on the core features of effective professional development (e.g., Desimone, 2009; Johnson \& Fargo, 2010; Penuel, Fishman, Yamaguchi, \& Gallagher, 2007), (b) promote teaching with technology in classrooms (e.g., Sadik, 2008), and (c) benefit SWLDs (e.g., Harris, Graham, \& Adkins, 2015). The current project's face-to-face professional development model, designed to prepare teachers to instruct students in online research strategies with the SOAR Student Toolkit, was developed using evidence-based principles for well-designed professional development and was grounded in prior research. The model was designed to incorporate specific, high-quality activities, lectures, discussions, and materials. These materials included handouts that link Common Core State Standards with the strategies, instructional planning documents, examples of student outputs, and protocols for measuring student success. In particular, the S-SOAR professional development model incorporated four of Desimone's (2009) five components of effective professional development with a content focus, active learning, coherence, and collective participation, described in detail below. The fifth component - duration - was the only feature that was unmet; given the structured nature of the SOAR Student Toolkit, we believed effective professional development for this intervention would not require a considerable amount of time from teachers to learn about its content and technological requirements. Unlike other comprehensive core programs, the SOAR Student Toolkit teaches nine specific strategies that do not require a lot of time for adults to learn; also, its online instructional materials are ready to use in the classroom with limited planning time.

Project S-SOAR's professional development model is a 1-day (5 hours), face-to-face workshop with project staff and teachers present. The first professional development session was conducted across 2 days, but staff learned that this additional time for planning and the activities was not needed, so from then on used a 1-day format. Prior to the workshop, teachers are asked to review the nine strategies for online academic research and come prepared with a research topic with which to practice the strategies, though teachers are told that they may use the "Are zoos good for the planet?" topic already embedded into the website if they prefer (approximately 2 hours). The workshop incorporates brief overview lectures from project staff which are supported by more indepth handouts, collaboration in whole-group discussion activities, and independent activities that teachers complete on their own or with a partner on a computer or tablet. The project aimed for a high level of quality of materials and activities in order to be maximally useful to teachers in learning about the strategies and how to implement them in their classrooms. The session begins with introductions (5 minutes), a project description (15 minutes), and an explanation of the teacher's role (10 minutes).

The first phase of the professional development (30 minutes), as recommended by Berry and colleagues (2011), targets instruction for SWLDs. The primary purpose of this phase is to provide teachers with the means to support SWLDs as they learn the strategies so that they can succeed alongside general education students. Teachers learn how SWLDs struggle with executive function skills involving memory, especially in working memory, cementing learned information into long-term memory, and retrieving learned information. Within this 30-minute session, teachers are briefly shown how the strategies map to Guinee's (2004) research process model so that they understand the technical and cognitive skills involved in each part of the research process that students will learn (see Appendix A). Teachers can see how to support struggling students by focusing instruction, segmenting new concepts, using practice exercises, and minimizing redundancy. The professional development also informs teachers about how to use technology effectively with SWLDs, and how the SOAR Student Toolkit facilitates learning for SWLDs in general as well as for students with specific learning disabilities - topics that align with well-designed professional development practices for educators of SWLDs (Berry et al., 2011). Finally, teachers 
review a checklist of key principles for reducing cognitive load. Then, teachers review how the SOAR Student Toolkit provides natural pacing, manageable activities, multimodal content delivery, real-world research tasks, and encouragement to make and correct mistakes. They learn how to help SWLDs take advantage of these features and create their own learning environments to support self-paced learning and autonomous decision-making.

The second phase of the professional development (1 hour) has a content focus, demonstrating the linkage between the strategies and the ways students learn the strategies with the SOAR Student Toolkit, such as with videos, practice questions, and authentic performance tasks. Project staff provided teachers with an example of a digital notebook - the final product that students will accomplish - so that teachers have that product in mind when providing instruction (see Appendix B). A digital notebook is an online document created with a word processor (e.g., Google Docs, MS Word), in which students record online research activities as they learn each of the nine strategies. This notebook shows the progression of research from its conception (original research questions) to its final development (an outline with notes derived from student research). To assess student work, teachers are shown how to use teacher rubrics for scoring both formative assignments and pre- and posttests (see Appendix C). They also see how to use student rubrics to help students score their own formative assignments and actively engage in the teaching-learning process (see Appendix D). With scoring rubrics, teachers identify the crucial skills that students need to conduct effective online research and meet Common Core State Standards for English Language Arts (Bulgren, Sampson Graner, \& Deshler, 2013) (see Appendix E).

The third phase ( 2 hours) incorporates active learning, coherence and collective participation. In this phase, teachers actively learn and experience the curriculum, complete a Readiness Inventory to compare the consistency of professional development content and discussions with their own knowledge and beliefs, and are encouraged to participate collectively in face-to-face and virtual meetings during implementation. To help them see how to teach each strategy most effectively, teachers review each strategy from both instructor and learner perspectives. In this way, they gain knowledge and confidence with using both the curriculum and the technology in their classrooms (Ritzhaupt, Dawson, \& Cavanaugh, 2012; Walker et al., 2012). As they review each strategy, teachers fill out an Instructional Planning Matrix (IPM), in which they design a content-based project for their classrooms that includes the online research strategies (see Appendix F). On the IPM, teachers write down what they think students need to know prior to the strategy, how long it will take to teach, any recommended teaching methods, and how student understanding will be formatively assessed. After independently working on their planning templates, teachers discuss them as a group, so that teachers can share how they would teach the one to two strategies they have been assigned. In this way, teachers share, collaborate on instruction ideas, and learn from each other.

The fourth phase (1 hour) involves project staff working out study logistics with teachers, and helping them one-on-one and independently to plan their upcoming unit. During this time, teachers complete a Readiness Inventory that asks about the school's support for using technology, the school's structural capabilities for technology implementation, the teacher's level of expertise with using technology for educational tasks, the ways teachers use technology in their classrooms, the ways students use technology at school and at home, and the potential need for teaching the strategies to students.

Finally, in keeping with research by Ertmer and colleagues (2012), project staff encourage teachers to form learning communities that will meet periodically to discuss, with each other and project staff, issues and ideas that arise during implementation. At these learning community sessions, teachers may be prompted by project staff to consider what has been challenging that week, or what specific activities have worked well. Teachers have the opportunity during these sessions to give and receive one-on-one support from project staff and to bring up issues with which they 
may receive immediate assistance. These collaborations promote discussions between teachers, as well as with project staff, and encourage ongoing virtual and face-to-face professional development. There were a total of six of these periodic face-to-face teacher coaching meetings in the three implementations combined, with project staff meeting virtually and/or face-to-face with the teachers. Discussion topics included status on implementing the strategies, technology problemsolving, and ideas for improvements to the intervention, among others.

\section{Literature Review}

A wide range of learning activities can be defined as professional development (Desimone, 2009). Just a few examples of professional development activities are formal or informal learning communities among teachers (e.g., Little, 1999, 2002; Mathews, Holt, \& Arrambide, 2014; McLaughlin \& Talbert, 1993; Stein, Smith, \& Silver, 1999), co-teaching and mentoring (Pancsofar \& Petroff, 2013; Schifter \& Fosnot, 1993), reflecting on lessons (Diamond, Maerten-Rivera, Rohrer, \& Lee, 2014; Schifter \& Fosnot, 1993), group discussions (Ball \& Cohen, 1999; Gearhart \& Wolf, 1994), study groups (Greenleaf, Schoenbach, Cziko, \& Mueller, 2001), own inquiry/action research (Guskey, 2000; Nadelson et al., 2013), and designing new curricula (Guskey, 2000; Little, 1993).

Desimone (2009) suggests that professional development effectiveness should be measured, not by the type of professional development (e.g., workshop or study group), but by the characteristics of the activities (e.g., content focus, coherence, and duration) that help increase teacher learning, change practice, and improve student outcomes. In her work, Desimone (2009) proposed a core conceptual framework for studying professional development, which includes five critical features to increase teacher knowledge, change practice, and improve student outcomes: (a) content focus (showing teachers the linkage between subject matter and how students learn that content), (b) active learning (interactive feedback and discussions during professional development sessions), (c) coherence (consistency between professional development feedback and discussions and teachers' knowledge and beliefs), (d) collective participation (ongoing professional development with teacher groups), and (e) duration (at least 20 hours of professional development).

Several studies have documented the effectiveness of this set of core features. Johnson and Fargo (2010) conducted a longitudinal study of middle school science teachers who participated in the Discovery Model Schools initiative, which was followed by 1-day periodic professional development sessions. The Discovery Model included the five core features of effective professional development. Results of multiple-regression analyses that adjusted for clustering of students within classrooms indicated that students of teachers who received the sustained, whole-school professional development scored significantly higher on science proficiency tests than controls. Thus, the findings provide evidence that teacher participation in effective professional development has a positive impact on students' achievement in science.

Penuel and colleagues (2007) also studied the effectiveness of a professional development model that integrated the five core features of effective professional development, using a sample of 454 teachers in an inquiry science program who received professional development over 2 years. Survey results indicated that professional development activities had a significant impact on science program implementation, but that the professional development design elements that mattered most for program implementation varied depending on the aspect of implementation being measured (e.g., teacher preparedness, data reporting, fidelity to protocol). Focus on content, active learning strategies, coherence, and collective participation supported the various outcomes; however, greater duration of professional development did not necessarily have a positive impact.

High-quality professional development is especially important for enhancing student learning with technology (Sadik, 2008). Professional development that incorporates technology integration 
has been shown to result in more positive and sophisticated beliefs among teachers about using technology in their teaching (Campbell, Zuwallack, Longhurst, Shelton, \& Wolf, 2014).

Ritzhaupt, Dawson, and Cavanaugh (2012) found that students made better use of technology for learning when it was integrated effectively by their teachers into the curriculum, which could be enhanced by teachers' prior technology experiences. Walker et al. (2012) implemented a professional development program with teachers that taught best instructional practices for using online learning resources and creating online problem-based learning activities. The researchers found that teachers who received the professional development self-reported gains in knowledge and use of problem-based learning activities and technology integration. In addition, students selfreported increases from pre- to post-implementation in their attitudes and behaviors towards learning the content and in their content knowledge. For teachers to make the most of technology for learning, they require professional development that increases knowledge and confidence with using technology, includes insights into how students can assist teachers with using technology, incorporates practice with the technology tools, and offers guidance for creating or joining learning communities (Ertmer et al., 2012)

Well-designed professional development is especially important for enhancing learning for SWLDs (Browder et al., 2012; Harris et al., 2015; Wasik \& Hindman, 2011). Studies show that professional development for special education is most helpful when it goes beyond curriculum content and also offers teachers information about technology, an understanding of specific disabilities, and knowledge about special education (Berry et al., 2011). Researchers have found that challenges and opportunities exist within the context of literacy learning for SWLDs and highlight the need for professional development to help teachers acquire new technical skills associated with the Common Core State Standards for English Language Arts and needs of their students (Bulgren et al., 2013). Several studies have shown that professional development can support learning with technology for SWLDs. For example, in a study of preschool teachers, professional development training in assistive technology improved outcomes when teachers integrated this technology in the classroom with their students, including SWLDs (Parette et al., 2013). At-risk pre-schoolers also have been shown to benefit in media-integrated literacy instruction when taught by teachers who received effective professional development (Penuel et al., 2012).

This report discusses research designed to test a face-to-face professional development model based on these important research findings, specifically using Desimone's (2009) components of effective professional development, with an emphasis on providing teachers with information on specific disabilities and knowledge about special education. This professional development was created to prepare teachers for classroom implementation of the web-based SOAR Student Toolkit curriculum for teaching students the nine strategies for online academic research (SOAR). The following section reviews the SOAR literature and strategies.

\section{Strategies for Online Academic Research (SOAR)}

In the first phase of Project S-SOAR, a face-to-face professional development model was designed to prepare teachers for classroom implementation of the web-based SOAR Student Toolkit curriculum. The SOAR Student Toolkit can be accessed at http://ssoar.uoregon.edu/ with a free log-in. The SOAR Student Toolkit presents a step-by-step approach for learning and using nine strategies for online academic research (SOAR). The strategies and toolkit were based on 25 years of research and development in computer-based learning environments by the University of Oregon (e.g., Anderson-Inman \& Ditson, 1999; Anderson-Inman, Knox-Quinn, \& Horney, 1996; Anderson-Inman, Knox-Quinn, \& Szymanski, 1999; Anderson-Inman \& Reinking, 1998) and online reading and new literacies by the University of Connecticut's New Literacies Lab (Leu, 2000, 2002, 2011). 
From this research emerged an understanding of how SWLDs effectively learn and read online and, in particular, how they learn to conduct research online. Anderson-Inman, Richter, and Frisbee (2009) found that SWLDs can use online resources to learn effective, evidence-based study strategies, especially when the strategies are broken down into simple steps; allow students to learn through reading, writing, and/or studying for a specific purpose (such as note-taking from a textbook); and incorporate technology for learning purposes. Leu and Kinzer (2000) also found that strategies for reading online were different than strategies for reading on paper. The converging work of Drs. Anderson-Inman, Leu, and others have been incorporated into the SOAR Student Toolkit, as detailed below.

1. For each of the nine strategies, students begin by watching an introductory video that makes explicit the expectations for that strategy (Gersten et al., 2008; Haager \& Vaughn, 2013).

2. Students receive step-by-step instruction for each strategy (see Figure 1), broken down into tasks (Swanson, 2001) that teach specific cognitive strategies (Gersten \& Baker, 2001) through a series of brief videos.

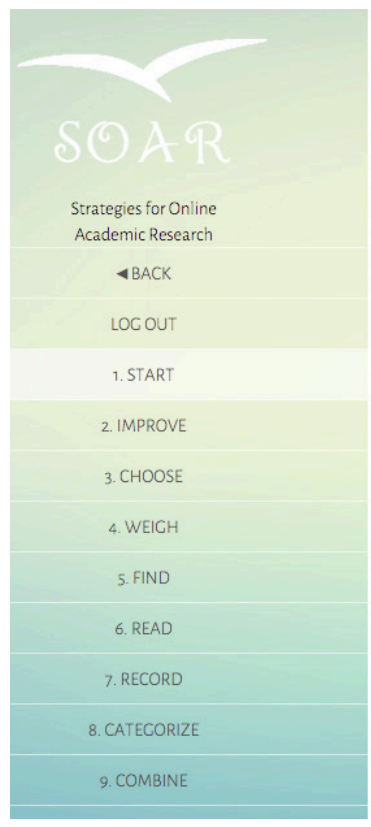

\section{STRATECY 1: Starting a Web Search}

\section{Introduction - When to Use It}

You need to do a Web search to get more information

You are looking for the right words to type into a search box.

Step 1 - Type

Open a Digital Notebook

Brainstorm questions starting with: Who, What, Why, Where, When, or How.

Always save your Digital Notebook because you will use it during your whole search.

Step 2 - Tidy Up

Spell Check and make your question Google-Ready

Step 3 - Transfer

Transfer your results.

Copy and Paste from your Digital Notebook into the Google search box

Press the Enter key.

TRY IT NOW

Figure 1: SOAR Student Toolkit stepwise instruction

3. After watching each video, students complete a multiple-choice formative assessment (see Figure 2) to practice what they have learned and to foster ownership of the strategy, leading to modifications of the strategy if necessary (Beckman, 2002; Yin, Tomita, \& Shavelson, 2014). 


\section{STRATECY THREE-CHOOSINGCOODSITES-STEPTWO:FINDNON-COMMERCIALSITES}

\section{PRACTICE Q1: Match .org, edu, gov, and .com with their descriptions by choosing one from each of the drop down menus below.}

\section{0:38}

\begin{tabular}{|c|c|}
\hline An organizational websi & terg \\
\hline An educational website & edu \\
\hline A governmental website & Selectyour answer \\
\hline A commercial website & $\checkmark$ Select your answer \\
\hline & .edu \\
\hline & .org \\
\hline & .com \\
\hline & .gov \\
\hline
\end{tabular}

Figure 2: Formative assessment example

4. Students review one-page strategy summaries (see Figure 3) to make expectations visible and remind them of crucial steps (Gersten \& Baker, 2001).

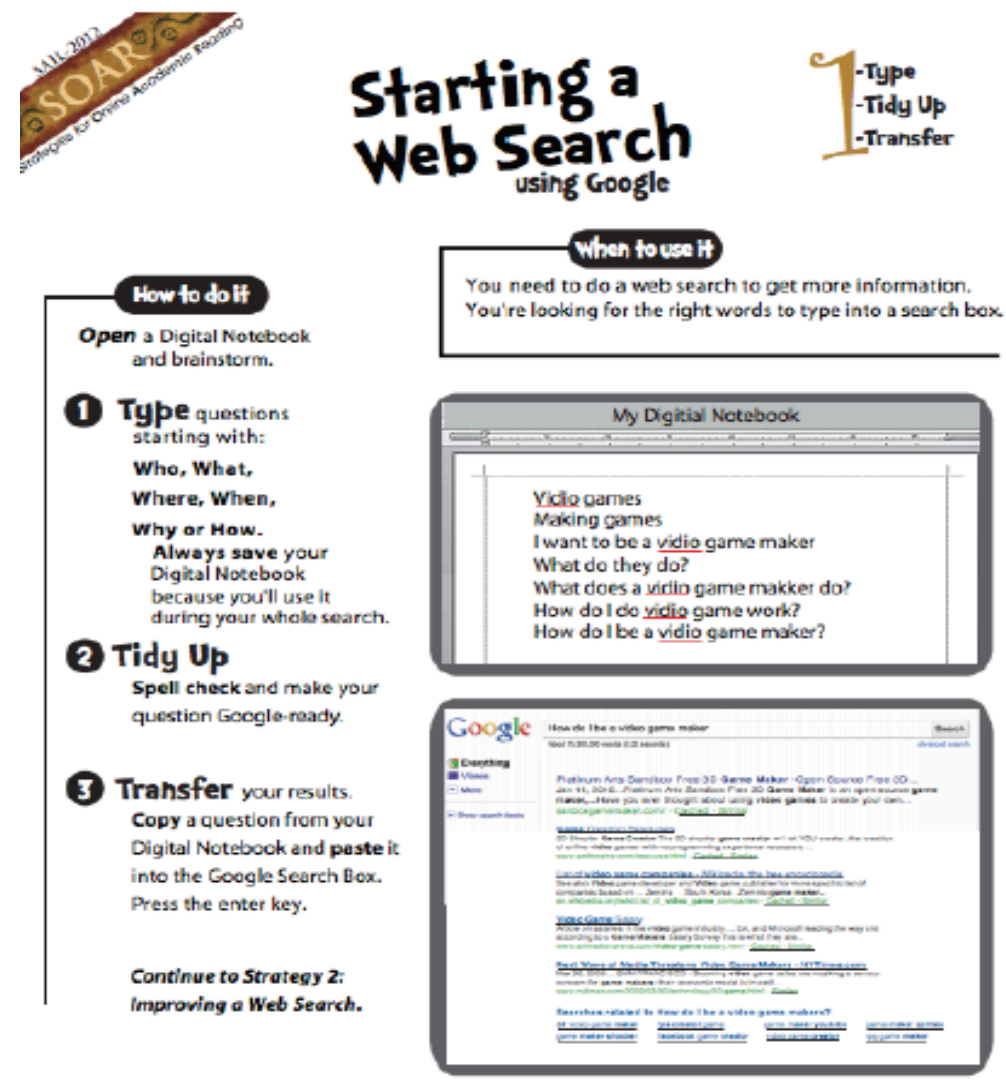

$\mathbf{O}$

Figure 3: Student one-page handout 
5. Students apply each strategy to academic material, and make the content personally relevant (Ferretti \& Okolo, 1996; Jones, Scanlon, \& Clough, 2013) through a "Try It" summative assessment (see Figure 4) in which they consider the pros and cons of a real-world problem, such as whether zoos are good for the planet.

\section{Strategy 1 - Try lt!}

The big idea for this Try It! is to create a Digital Notebook and brainstorm good search questions on the following topic: Zoos are good for the planet: agree or disagree.

\section{Do This to Get Ready}

1. Start a new Digital Notebook.

2. Save it to your desktop or student folder.

3. Name it using your name and your topic. For example, CaseyZoo.doc is Casey's notebook about Zoos.

\section{$\underline{O k, G O !}$}

1. Brainstorm and type search questions in your notebook.

- Start your questions with questioning words (Who, What, Why, When, Where, and How) when possible.

- Use the most specific words you know.

2. Tidy Up at least three questions to make them Google-Ready. Be sure to use Spell Check.

3. Save your Digital Notebook.

\section{Figure 4: "Try It" authentic research assignment}

Although the SOAR Student Toolkit was designed for all students, built-in features offer additional and specific support for SWLDs. The strategies are grounded in prior research for best practices for teaching SWLDs in that they:

(a) Are anchored in authentic, problem-solving tasks (Gersten, 1998; U.S. Department of Education, 2010).

(b) Provide multiple learning methods, such as audio and video options (students may read text on how to complete the strategy steps, and/or may watch and listen to videos about the strategy steps) (Anderson-Inman \& Horney, 1998), and include video tutorials with avatars that provide modeling and emphasize practice (videos depict student and teacher avatars modeling how to complete the strategy steps) (Gersten, Fuchs, Williams, \& Baker, 2001).

(c) Focus on cognitive and meta-cognitive skills, triggering students to generate questions while problem-solving (for instance, for the first two strategies, students create and edit research questions based on a real-world problem encountered in their "Try It" assignments) (Gersten et al., 2001).

(d) Encourage task persistence and active learning (students engage in active learning tasks such as creating better research questions or finding better information from the Internet, prompted from strategies and Try It assignments designed specifically to enhance task persistence) (Beckman, 2002). 
(e) Include modules for individualized instruction (each of the nine strategies is housed on its own page) (Swanson, 2001).

(f) Use technology that supports learning and learning outcomes for students (students actively engage with computers or tablets or laptops with the purpose of learning and practicing the strategies as well as learning technology tips and how to use eText supports, such as text to speech) (Anderson-Inman \& Horney, 2007).

(g) Control the difficulty of student tasks (the overarching task of constructing a research outline in the digital notebook is broken down into nine strategies to limit cognitive overload) (Vaughn, Gersten, \& Chard, 2000).

The SOAR Student Toolkit curriculum supports current instructional expectations. The Common Core State Standards (2010), which define what U.S. students should know and be able to achieve at each grade level, require that teachers help their students master digital tools and Internet research. Inherent in the Common Core State Standards is the recognition that the Internet is a primary source of knowledge in the information age (Leu et al., 2013; Levin \& Arafeh, 2002), and that web-based technology tools help promote student literacy, academic achievement, and engagement. Thus the SOAR Student Toolkit provides teachers with a comprehensive curriculum to help meet the Common Core State Standards for English Language Arts. In addition, the SOAR Student Toolkit addresses the need to educate SWLDs through online learning to assist with their individual requirements and provide personalized learning, emphasized by the National Center for Learning Disabilities (Cortiella \& Horowitz, 2014).

\section{Methods}

The purpose of this paper is to describe the implementation and impact of a face-to-face professional development model to enable teachers to implement the SOAR Student Toolkit for teaching online research strategies to middle school general education students and SWLDs. Based on data from three groups of teachers across 2 academic years, the present investigation documents teachers' perceptions of the professional development program, as well as the extent to which teachers completing the program succeeded in teaching the SOAR Student Toolkit and positively impacting students' academic research skills.

The following research questions were addressed:

1. What are teachers' overall ratings for the face-to-face professional development model designed to help them implement the online academic research curriculum?

2. What are students' and teachers' post-implementation perceptions of the SOAR Student Toolkit used in the classroom?

3. Is there a significant improvement in students' online academic research skills after being taught the SOAR Student Toolkit by teachers prepared with the face-to-face professional development model?

\section{Design}

A real-world test of the face-to-face professional development model, incorporating core features of effective professional development, was conducted in three implementations from 2013 to 2014: five teachers in fall 2013, four teachers in spring 2014, and six teachers in fall 2014. Participating teachers attended a professional development workshop led by project staff, and then implemented the SOAR Student Toolkit with students, including SWLDs, in their classrooms. 


\section{Participants}

A total of 15 teachers and 446 students participated in the study. Of the teachers, $80 \%$ were female, $100 \%$ were Caucasian, $80 \%$ taught language arts/social studies, and 20\% taught other subjects. On average, teachers had $15.8(\mathrm{SD}=8.9)$ years of experience as educators and $9.5(\mathrm{SD}=5.6)$ years at their present school. Of the students, $46.4 \%$ were female, $71.3 \%$ were Caucasian, $60.5 \%$ were in sixth grade, $20.8 \%$ were in seventh grade, $18.8 \%$ were in eighth grade, $1.8 \%$ were English language learners, and 19.1\% were SWLDs. On average, students scored $226.4(\mathrm{SD}=8.4)$ on the reading assessment of Oregon's Assessment of Knowledge and Skills. Based on Oregon Assessment of Knowledge and Skills established cut scores, $30.6 \%$ of the students did not meet the reading achievement standard, $44.9 \%$ met the standard, and $24.4 \%$ exceeded the standard.

\section{Measures}

Data were gathered from multiple sources, including teacher and student surveys, and pre- and post-intervention assessments collected from students.

After the professional development workshop, teachers completed a short survey evaluating the activities, using a Likert-type scale to indicate agreement with different statements. Items included the extent to which the training was high quality, the pace and format were appropriate, the activities gave sufficient practice and feedback, and the training supported professional growth in providing differentiated instruction to students and supported professional growth in integrating technology into instruction.

After implementing the SOAR Student Toolkit in their classrooms, teachers were asked to complete a survey to document their satisfaction with the project. On a Likert-type scale, teachers rated the extent to which they found the SOAR Student Toolkit and the professional development they received to be of high quality, as well as relevant to improving outcomes for SWLDs.

Students completed a short post-implementation survey to gauge their satisfaction with the SOAR Student Toolkit. On a Likert-type scale, students rated the extent to which the strategies helped them to learn, whether they would use the strategies again, and how comfortable they felt conducting research online.

Students completed 40-minute pretest and posttest performance-based assessments to document their ability to search for, find, evaluate, read, and utilize appropriate and relevant information when reading and researching online. Each student was randomly assigned to one of two different research scenarios and asked to complete a digital notebook to demonstrate his or her use of the strategies. One scenario asked students to research whether a city should ban plastic bags to improve the environment. The other scenario asked students to research whether a school should change its schedule to make school start later to improve student performance. These assessments were scored by project staff trained to a high level of inter-rater reliability (Kappa $=.80)$ using a 21-point rubric; the maximum score of 21 points reflects completion of all strategies instruction. The measure demonstrated good internal consistency in this study (Cronbach's alpha $=.89$ at pretest).

Performance-based assessment scores were recoded into four levels of mastery (Rosenberg, 2012) to determine the degree to which students obtained mastery level proficiency in conducting online research. Rosenberg's four mastery levels are defined as follows: (a) novice (or apprentice) - by definition, new to a job, students know little or nothing about the tasks, too little to be able to perform to any acceptable standard; (b) competent (or journeyman) - students can perform tasks to basic standards; (c) experienced - students are beyond merely competent and can vary their performance based on unique situations; and (d) master - students create new knowledge or invent new and better ways to do a job, and can teach others how to do it. In the present study, perfor- 
mance-based assessment percentage scores were recoded so that scores lower than $43 \%$ were considered novice level, scores equal to or higher than $43 \%$ but below $62 \%$ were considered competent level, scores equal to or higher than $62 \%$ but below $90 \%$ were considered experienced level, and scores equal to or higher than $90 \%$ were considered master level.

\section{Data Analysis}

All data were entered, cleaned, and inspected to ensure that distributions met assumptions of the statistical tests employed. Performance-based assessment raw total and percentage scores were calculated, and percentage scores were recoded into four levels of mastery.

Descriptive statistics were calculated to describe teacher perceptions of the professional development they received as well as satisfaction with the SOAR Student Toolkit. Descriptive statistics also were calculated to document student satisfaction with and perceptions of learning with the SOAR Student Toolkit.

To examine pretest-to-posttest change in performance-based assessment scores, a linear mixed model was conducted with the test percentage score as the dependent variable and "time" (coded 0 at pretest and 1 at posttest) as a fixed effect, accounting for nesting of students within teachers and specifying unconstructed covariance, restricted maximum likelihood estimation, and random intercept. An additional linear mixed model was conducted to examine whether results over time differed by SWLD status, EL status, gender, and grade; this model included main effects for each of these variables as well as their interactive effects with time.

\section{Results}

\section{Teacher Satisfaction with Professional Development}

Fourteen teachers rated the professional development workshops they attended. Results are summarized in Table 1. Teachers found the face-to-face professional development to be of high quality $(100 \%)$, to have an appropriate pace and format (93\%), and to provide activities with sufficient practice and feedback $(100 \%)$. All teachers said the training supported their professional growth in providing differentiated instruction to students and in integrating technology into their instruction.

Table 1: Teacher face-to-face professional development evaluation $(N=14)$

\begin{tabular}{|c|c|c|c|c|}
\hline & $\begin{array}{c}\text { Strongly } \\
\text { agree } \\
\%\end{array}$ & $\begin{array}{c}\text { Agree } \\
\%\end{array}$ & Disagree & $\begin{array}{c}\text { Strongly } \\
\text { disagree } \\
\%\end{array}$ \\
\hline Training was of high quality. & $50 \%$ & $50 \%$ & $0 \%$ & $0 \%$ \\
\hline Pace/format was appropriate. & $71 \%$ & $21 \%$ & $7 \%$ & $0 \%$ \\
\hline Activities gave sufficient practice and feedback. & $43 \%$ & $57 \%$ & $0 \%$ & $0 \%$ \\
\hline $\begin{array}{l}\text { Supported professional growth in providing differentiated } \\
\text { instruction to students. }\end{array}$ & $43 \%$ & $57 \%$ & $0 \%$ & $0 \%$ \\
\hline $\begin{array}{l}\text { Supported professional growth in integrating technology } \\
\text { into instruction }\end{array}$ & $79 \%$ & $21 \%$ & $0 \%$ & $0 \%$ \\
\hline
\end{tabular}




\section{Teacher Satisfaction Post-Implementation}

Fourteen teachers completed satisfaction surveys after implementing the SOAR Student Toolkit in their classrooms. Results are summarized in Table 2. Most teachers rated as "high quality" the SOAR Student Toolkit (86\%) and face-to-face professional development they received (71\%). Fewer teachers found the SOAR Student Toolkit (57\%) and face-to-face professional development $(57 \%)$ to be highly relevant to improving outcomes for SWLDs. Most teachers (60\%) said participation in learning communities was critical for the success of their SOAR Student Toolkit implementation.

Table 2: Teacher satisfaction after SOAR Student Toolkit implementation $(N=14)$

\begin{tabular}{|c|c|c|c|c|c|}
\hline & $\begin{array}{c}\text { Strongly } \\
\text { agree } \\
\%\end{array}$ & $\begin{array}{c}\text { Agree } \\
\%\end{array}$ & Neutral & Disagree & $\begin{array}{c}\text { Strongly } \\
\text { disagree } \\
\%\end{array}$ \\
\hline SOAR Student Toolkit of high quality. & $36 \%$ & $50 \%$ & $7 \%$ & $7 \%$ & $0 \%$ \\
\hline Professional development of high quality. & $21 \%$ & $50 \%$ & $14 \%$ & $14 \%$ & $0 \%$ \\
\hline $\begin{array}{l}\text { SOAR Student Toolkit highly relevant to improv- } \\
\text { ing outcomes for SWLDs. }\end{array}$ & $21 \%$ & $36 \%$ & $29 \%$ & $0 \%$ & $14 \%$ \\
\hline $\begin{array}{l}\text { Professional development highly relevant to im- } \\
\text { proving outcomes for SWLDs }\end{array}$ & $14 \%$ & $43 \%$ & $14 \%$ & $7 \%$ & $21 \%$ \\
\hline $\begin{array}{l}\text { Participation in professional learning communi- } \\
\text { ties critical for success of SOAR Student } \\
\text { Toolkit implementation }(n=5)\end{array}$ & $0 \%$ & $60 \%$ & $0 \%$ & $40 \%$ & $0 \%$ \\
\hline
\end{tabular}

\section{Student Satisfaction and Outcomes}

A total of 315 students completed satisfaction surveys after learning with the SOAR Student Toolkit. Results are summarized in Table 3. About half of the students agreed or strongly agreed that they were very happy with the use of the SOAR Student Toolkit, found it easy to use, believed it helped them learn strategies, and is a good way to teach; another one-quarter to one-third of students gave neutral responses to these items; and fewer students disagreed or strongly disagreed. In response to statements about whether the SOAR Student Toolkit was interesting and engaging, or boring and distracting, students were about equally divided between agreeing, disagreeing, and neither agreeing nor disagreeing. Most students said they would use the SOAR Student Toolkit for future research projects at least sometimes - and most students reported that they were at least somewhat comfortable locating and evaluating credible online resources.

On the performance-based assessment, 448 students provided data: 439 students completed the pretest, 434 completed the posttest, and 426 completed both tests. Performance-based assessment percentage scores and results are presented in Table 4.

The linear mixed effects model predicting the performance-based assessment score from time indicated that students overall improved performance an average of 29.2 percentage points, from $31.3 \%(\mathrm{SD}=22.1)$ at pretest to $60.5 \%(\mathrm{SD}=23.0)$ at posttest - a statistically significant increase $(F(d f=1,857)=468.4, p<.001)$.

Patterns of performance-based assessment score levels and gains differed by SWLD and English language learner status, gender, and grade, based on results of the linear mixed effects model that included these variables as well as time. 
Table 3: Student satisfaction after SOAR Student Toolkit implementation $(N=315)$

\begin{tabular}{|c|c|c|c|c|c|}
\hline & $\begin{array}{c}\text { Strongly } \\
\text { agree } \\
\%\end{array}$ & Agree & Neutral & Disagree & $\begin{array}{c}\text { Strongly } \\
\text { disagree } \\
\%\end{array}$ \\
\hline $\begin{array}{l}\text { Very happy with use of } \\
\text { SOAR Student Toolkit. }\end{array}$ & $8 \%$ & $44 \%$ & $33 \%$ & $9 \%$ & $5 \%$ \\
\hline $\begin{array}{l}\text { SOAR Student Toolkit } \\
\text { very easy to use. }\end{array}$ & $16 \%$ & $43 \%$ & $24 \%$ & $13 \%$ & $4 \%$ \\
\hline $\begin{array}{l}\text { SOAR Student Toolkit } \\
\text { helped with learning } \\
\text { strategies. }\end{array}$ & $16 \%$ & $55 \%$ & $20 \%$ & $6 \%$ & $3 \%$ \\
\hline $\begin{array}{l}\text { SOAR Student Toolkit } \\
\text { good way to teach. }\end{array}$ & $16 \%$ & $39 \%$ & $27 \%$ & $13 \%$ & $5 \%$ \\
\hline $\begin{array}{l}\text { SOAR Student Toolkit } \\
\text { interesting and engag- } \\
\text { ing. }\end{array}$ & $9 \%$ & $22 \%$ & $33 \%$ & $21 \%$ & $16 \%$ \\
\hline \multirow{2}{*}{$\begin{array}{l}\text { SOAR Student Toolkit } \\
\text { boring and distracting. }\end{array}$} & $19 \%$ & $18 \%$ & $29 \%$ & $24 \%$ & $10 \%$ \\
\hline & $\begin{array}{c}\text { Always } \\
\%\end{array}$ & $\begin{array}{c}\text { Most of the } \\
\text { time } \%\end{array}$ & $\begin{array}{c}\text { Sometimes } \\
\%\end{array}$ & $\begin{array}{c}\text { Rarely } \\
\%\end{array}$ & $\begin{array}{c}\text { Never } \\
\%\end{array}$ \\
\hline $\begin{array}{l}\text { Will use SOAR in future } \\
\text { research projects. }\end{array}$ & $9 \%$ & $27 \%$ & $35 \%$ & $16 \%$ & $14 \%$ \\
\hline
\end{tabular}

$\begin{array}{cccccc} & \begin{array}{c}\text { Very } \\ \text { comfortable }\end{array} & \text { Comfortable } & \begin{array}{c}\text { Somewhat } \\ \text { comfortable }\end{array} & \text { Uncomfortable } & \text { Very } \\ \text { uncomfortable } \\ \%\end{array}$
evaluating online resources.

On average, SWLDs had lower performance-based assessment score levels $(19.0 \%$ [SD $=18.9]$ at pretest and $49.7 \%[\mathrm{SD}=25.4]$ at posttest) than general education students $(34.0 \%[\mathrm{SD}=22.0]$ at pretest and $63.0 \%[\mathrm{SD}=21.9]$ at posttest $)$, a significant main effect for SWLD status: $F(d f=$ $1,349)=17.9, p<.001$. However, both groups improved about the same over time $(30.6 \%$ for SWLDs and $29.0 \%$ for general education students).

As with SWLDs, English language learners on average had lower performance-based assessment score levels $(4.8 \%[\mathrm{SD}=10.6]$ at pretest and $33.3 \%[\mathrm{SD}=19.3]$ at posttest) than Englishproficient students $(31.4 \%$ [SD $=22.1]$ at pretest and $60.8 \%$ [SD $=22.9]$ at posttest $)$, a significant main effect for English language learner status: $F(d f=1,830)=4.3, p=.04$. Both groups gained about the same over time (28.5\% for English language learners and 29.4\% for English-proficient students).

Females had lower scores than males on the pretest $(29.9 \%$ [SD $=22.0]$ and $32.6 \%$ [SD $=22.1]$, respectively), but higher scores at posttest $(62.3 \%$ [SD $=22.9]$ and $59.1 \%$ [SD $=22.9]$, respectively), indicating greater gains for females $(32.4 \%)$ compared to males $(26.5 \%)$. The gender-bytime interaction was statistically significant: $F(d f=1,821)=4.0, p<.05$. 
Table 4: Student performance-based assessment scores and results $(N=448)$

\begin{tabular}{|c|c|c|c|c|}
\hline & $\begin{array}{l}\text { Pretest Mean } \\
\quad \%(S D)\end{array}$ & $\begin{array}{c}\text { Posttest } \\
\text { Mean \% (SD) }\end{array}$ & $\begin{array}{c}\% \\
\text { Increase }\end{array}$ & $F(d f) ; p$ \\
\hline All Students $(N=448)$ & $31.3 \%(22.1)$ & $60.5 \%(23.0)$ & $29.2 \%$ & $\frac{\text { Time main effect: }}{468.4(1,857) ;<.001}$ \\
\hline General Education Students $(n=356)$ & $34.0 \%(22.0)$ & $63.0 \%(21.9)$ & $29.0 \%$ & $\underline{\text { SWLDs main effect: }}$ \\
\hline SWLDs $(n=84)$ & $19.0 \%(18.9)$ & $49.7 \%(25.4)$ & $30.6 \%$ & $17.9(1,349) ;<.001$ \\
\hline English-proficient Students $(n=428)$ & $31.4 \%(22.1)$ & $60.8 \%(22.9)$ & $29.4 \%$ & ELs main effect: \\
\hline English Language Learners $(n=8)$ & $4.8 \%(10.6)$ & $33.3 \%(19.3)$ & $28.5 \%$ & $4.3(1,830) ; .04$ \\
\hline Males $(n=239)$ & $32.6 \%(22.1)$ & $59.1 \%(22.9)$ & $26.5 \%$ & $\underline{\text { Gender-by-time }}$ \\
\hline Females $(n=207)$ & $29.9 \%(22.0)$ & $62.3 \%(22.9)$ & $32.4 \%$ & $\frac{\text { interaction effect: }}{4.0(1,821) ;<.05}$ \\
\hline Grade $6(n=271)$ & $26.6 \%(20.0)$ & $58.3 \%(23.6)$ & $31.7 \%$ & $\underline{\text { Grade-by-time }}$ \\
\hline Grade $7(n=93)$ & $27.9 \%(24.7)$ & $61.4 \%(25.3)$ & $33.5 \%$ & $\underline{\text { interaction effect: }}$ \\
\hline Grade $8(n=84)$ & $50.4 \%(13.7)$ & $66.9 \%(16.1)$ & $16.5 \%$ & $13.2(1,821) ;<.001$ \\
\hline
\end{tabular}

Eighth-grade students had higher scores than sixth- and seventh-grade students on the pretest (sixth grade $=26.6 \%[\mathrm{SD}=20.0]$; seventh grade $=27.9 \%[\mathrm{SD}=24.7]$; eighth grade $=50.4 \%[\mathrm{SD}$ $=13.7]$ ), but all grades had similar scores at posttest ( sixth grade $=58.3 \%[\mathrm{SD}=23.6]$; seventh grade $=61.4 \%[\mathrm{SD}=25.3]$; eighth grade $=66.9 \%[\mathrm{SD}=16.1])$, indicating greater gains among sixth- and seventh-grade students ( sixth grade $=31.7 \%$; seventh grade $=33.5 \%$ ) relative to eighth-grade students $(16.5 \%)$. The grade-by-time interaction was statistically significant: $F(d f=$ $1,821)=13.2, p<.001$.

Performance-based assessment mastery results are presented in Table 5. At pretest, 299 students were at the novice level, 98 students were at the competent level, 28 students were at the experienced level, and 2 students were at the master level.

Table 5: Performance-based assessment mastery results $(N=448)$

\begin{tabular}{lcccc} 
& \multicolumn{2}{c}{ Pretest Level } \\
Posttest Level & Novice & Competent & Experienced & Master \\
Novice $(n=299)$ & $26.1 \%$ & $31.4 \%$ & $38.1 \%$ & $4.3 \%$ \\
Competent $(n=98)$ & $5.1 \%$ & $18.4 \%$ & $70.4 \%$ & $6.1 \%$ \\
Experienced $(n=28)$ & $0 \%$ & $14.3 \%$ & $78.6 \%$ & $7.1 \%$ \\
Master $(n=2)$ & $0 \%$ & $0 \%$ & $50 \%$ & $50 \%$
\end{tabular}

Most students who began at novice and competent levels improved at least one level of mastery from pretest to posttest ( $73.9 \%$ of novices and $76.5 \%$ of competent students). Most experienced 
students at pretest remained at the same level at posttest (78.6\%). One of the two students who began at the master level remained there; the other moved down to the experienced level. A McNemar-Bowker test determined that there was statistically significant change in the proportion of students within the four levels of mastery from pretest to posttest, $p<.001$.

\section{Discussion}

The purpose of this study was to document the degree to which a face-to-face professional development model prepared teachers to implement an online academic research curriculum with students in the classroom. Results show that the professional development was effective, as measured by teacher satisfaction with the professional development and the curriculum as well as by student satisfaction and pre-post implementation improvement in online research skills. Thus, the present study provides evidence that the activities performed as core features of this face-to-face professional development and the inclusion of high-quality, relevant instructional materials enhanced digital learning for both general education students and SWLDs. These results are in line with previous research supporting the effectiveness of face-to-face professional development that is designed with the five core features of effective professional development in improving student learning outcomes. As in prior research, teachers in the present study who completed the face-toface professional development became more knowledgeable about the professional development subject matter (Robinson, Myran, Strauss, \& Reed, 2014), and had a positive impact on students' performance related to that subject (Lumpe, Czerniak, Haney, \& Beltyukova, 2011). Because the face-to-face professional development for this project was designed specifically to train teachers to implement the SOAR Student Toolkit, it is not surprising that trained teachers were found to be effective in improving student online academic research through the use of the SOAR Student Toolkit. With the knowledge gained in the face-to-face professional development, teachers had a clear understanding of the strategies and technology they taught in their classrooms.

Especially salient are results showing the impact of face-to-face professional development on teachers' self-reported knowledge gains and confidence. As in other studies (Campbell et al., 2014; Walker et al., 2012), teachers in the present investigation indicated after the professional development that they grew professionally in understanding how to provide differentiated instruction to students and in integrating technology into their instruction. These topics are critical for teaching strategies for online academic research, and the results show that the face-to-face professional development provided reasonable coverage with relevant discussions and high-quality materials focused on differentiated instruction.

Results from teacher ratings indicate that the face-to-face professional development, based on Desimone's (2009) methods for effective professional development, was well designed. Despite its relatively short duration of 1 day and three follow-up teacher coaching meetings, the professional development in this project appeared to be sufficient for preparing teachers to implement the structured SOAR Student Toolkit curriculum. Previous research showing that short-term, evidence-based teacher professional development can have long-lasting effects (Ha, Baldwin, \& Nehm, 2015) suggests that the effects in the present study may be sustained over time. After the professional development, all teachers reported that the professional development was of high quality and provided enough practice and feedback, and nearly all teachers found it to have an appropriate pace and format. After implementing the SOAR Student Toolkit with their students, about three-fourths of teachers continued to report that the professional development was of high quality in post-implementation surveys. These findings confirm prior research of the need for professional development to be well designed in order to enhance student success (Ertmer et al., 2012), especially for SWLDs (Browder et al., 2012; Harris et al., 2015).

Student success is the ultimate goal of teacher professional development, as it reveals the extent to which teachers were prepared to implement the curriculum. Despite limitations in drawing in- 
disputable conclusions between teacher preparation and student outcomes, the present study lends additional support to previously reported connections between effective professional development and student knowledge gains (Browder et al., 2012; Harris et al., 2015; Parette et al., 2013; Penuel et al., 2012; Ritzhaupt et al., 2012; Walker et al., 2012). In the current study, students significantly improved pretest to posttest scores on an authentic performance task requiring the use of online research skills. This was true for both general education students and SWLDs and was anticipated, given that the professional development focused specifically on classroom use of the SOAR Student Toolkit and included a discussion of student outcomes.

Success of SWLDs in particular was analyzed in this study. Teachers who were trained with the face-to-face professional development model successfully implemented the curriculum with SWLDs as well as general education students, as demonstrated by similar knowledge gains in both groups. The finding adds to the literature indicating that quality professional development is especially vital to improving learning outcomes for SWLDs (Browder et al., 2012; Harris et al., 2015). One key component of the face-to-face professional development in this study is instruction on technology integration, which is particularly beneficial for SWLDs' learning (Berry et al., 2011; Parette et al., 2013; Penuel et al., 2012).

Despite a generally positive response to the professional development, results suggest room for improvement in this model. While all teachers reported immediately afterward that the professional development was of high quality, only about three-quarters of teachers continued to say so after implementation. Also, most teachers (86\%) rated the SOAR Student Toolkit as being of high quality after implementation, but only a little over half found the SOAR Student Toolkit or professional development to be highly relevant to improving outcomes for SWLDs. Decreases in confidence and changes in attitudes likely occurred when teachers experienced the demands of actually integrating the web-based SOAR Student Toolkit into their classrooms. Teachers confronted challenges and may have felt less confident that the professional development prepared them to meet these challenges. It should be noted that when teachers rated the relevance of the professional development for SWLDs, they were unaware of data showing significant knowledge gains for both general education students and SWLDs. The decrease in teacher ratings, especially regarding SWLDs, also might reflect shortcomings in the overall quality of the face-to-face professional development. The professional development focuses heavily on online research strategy integration and may not sufficiently address issues in SWLD education - even though the strategies, and especially the SOAR Student Toolkit, were created with SWLDs in mind. The professional development model could be improved by adding a component to specifically address challenges in implementing the curriculum in the classroom with both general education students and SWLDs and by adding a checklist for teachers after the professional development to identify which aspects of the curriculum and technology they have learned and which they should review and relearn prior to implementation. Future professional development sessions could better demonstrate how specific curriculum and technology features of the SOAR Student Toolkit may be applied to benefit SWLDs. In the professional development session, trainers and teachers could be encouraged to share their personal experiences in instructing SWLDs; trainers could describe specific situations encountered with SWLDs, such as what to do when a student has low reading comprehension skills, along with potential solutions and recommendations to prepare teachers for those situations.

High-quality professional development for teachers is especially important in the digital age, as teachers strive to simultaneously learn new curricula and new technology. The results of this study show that well-designed face-to-face professional development, with the opportunity for face-to-face learning, sharing, and practice, and the inclusion of quality, relevant instructional materials, can have positive effects on both teacher and student knowledge, especially in the context of special education and digital learning. This professional development model can help 
teachers transition into using technology effectively in their instruction, and thus help students meet the Common Core State Standards (2010).

There are implications from this study for education researchers and practitioners, especially teacher education. These results provide an additional argument for the need for high-quality professional development and offer further evidence of the effects that face-to-face professional development can have on learning for both general education students and SWLDs. The overarching goal of this line of research is to provide evidence-based solutions for practice that contribute to more effective learning for students in the digital age.

\section{Limitations}

Results from this study are based on a relatively small sample size. The sample is adequate to offer insights for research and practice into teachers' perceptions and preferences, as well as students' perceptions and performance, stemming from a face-to-face professional development model. However, sample size is a limiting factor when generalizing these results to larger and more diverse populations. Also, with a small sample size, individual teacher performance could have an effect on the results; that is, an unusually high or low level of skill and fidelity of implementation from one or two teachers could impact the overall findings.

The quasi-experimental, one-group, pretest-posttest design used in this study is appropriate for initial development and testing of a new program. However, it presents threats to internal and external validity. Such a design does not control for potentially confounding factors, including extraneous variables such as history, testing, instrumentation, and regression artifacts; thus, it is not possible to absolutely identify the effect of the treatment. The preliminary results presented here do provide an indication of teacher attitudes about the professional development model, and show that positive changes in student outcomes are associated with learning the SOAR Student Toolkit from trained teachers.

\section{Conclusion}

This study reported preliminary results of a face-to-face professional development for middle school teachers to enhance their effectiveness in using technology to enhance students' online research skills. Specifically, the professional development was designed to prepare teachers to instruct students, especially SWLDs, in how to search for, find, evaluate, read, and utilize appropriate and relevant information when reading and researching online. Future studies should compare face-to-face professional development delivery with web-based professional development delivery to offer additional insights about the best methods for delivering professional development to teach technology skills and curriculum. Although the face-to-face professional development model described here provided useful opportunities for personal interaction and feedback, and was associated with positive perceptions and outcomes, it may be that a web-based professional development course would be just as effective, or more so. There are many benefits to learning in an online environment, such as interactivity, self-pacing, and flexibility. Further study might show that a hybrid of the two delivery methods, or that allowing teachers to choose their preferred delivery method, is most effective.

To enhance generalizability and dissemination, future research should be conducted with larger sample sizes, more ethnically and socioeconomically diverse participants, and a larger geographical area. Within a larger study, an exploration of factors that may affect teachers' perceptions of the face-to-face professional development model is warranted; such factors might include work experience, teaching specialty, and previous experience with technology. Future research into the development of high-quality professional development for teaching technology-based curricula 
Terrazas-Arellanes. Knox, Strycker, \& Walden

would be beneficial to educational researchers and practitioners, general education students, and SWLDs.

\section{References}

Anderson-Inman, L., \& Ditson, L. (1999). Computer-based concept mapping: A tool for negotiating meaning. Learning \& Leading with Technology, 26(8), 6-13.

Anderson-Inman, L., \& Horney, M. (1998). Transforming text for at-risk readers. In D. Reinking, L. Labbo, M. McKenna, \& R. Kieffer (Eds.), Handbook of literacy and technology: Transformations in a post-typographic world (pp.15-43). Mahwah, NJ: Lawrence Erlbaum.

Anderson-Inman, L., \& Horney, M. (2007). Supported etext: Assistive technology through text transformations. Reading Research Quarterly, 42(1), 153-160.

Anderson-Inman, L. \& Knox, C. (2009). Project SOAR: Strategies for online learning and academic research (Steppingstones Grant Award No. R324A100322). Washington, DC: U.S. Department of Education, Office of Special Education Programs.

Anderson-Inman, L., Knox-Quinn, C., \& Horney, M. (1996). Computer-based study strategies for students with learning disabilities: Individual differences associated with adoption level. Journal of Learning Disabilities, 29, 461-484.

Anderson-Inman, L., Knox-Quinn, C., \& Szymanski, M. (1999). Computer-supported studying: Stories of successful transition to postsecondary education. Career Development for Exceptional Individuals, 22, $185-212$.

Anderson-Inman, L., \& Reinking, D. (1998). Learning from text in a technological society. In C. Hynd, S. Stahl, B. Britton, M. Carr, \& S. Glynn (Eds.), Learning from text across conceptual domains in secondary schools (pp. 165-191). Mahwah, NJ: Lawrence Erlbaum.

Anderson-Inman, L., Richter, J., \& Frisbee, M. (2009, May). CBSS Online: Evaluating the impact of an online course in Computer-Based Study Strategies (CBSS). (Final report submitted to the U.S. Department of Education, Office of Special Education Programs.) Eugene, OR: Author.

Ball, D. L., \& Cohen, D. K. (1999). Developing practice, developing practitioners: Toward a practice-based theory of professional education. In L. Darling-Hammond \& G. Sykes (Eds.), Teaching as the learning profession. San Francisco, CA: Jossey-Bass.

Beckman, P. (2002). Strategy instruction. (ERIC Clearinghouse on Disabilities and Gifted Education, Council for Exceptional Children Digest No. E638). Retrieved December 9, 2015 from ERIC database. (ED474302).

Berry, A. B., Petrin, R. A., Gravelle, M. L., \& Farmer, T. W. (2011). Issues in special education teacher recruitment, retention, and professional development: Considerations in supporting rural teachers. $R u$ ral Special Education Quarterly, 30(4), 3-11.

Browder, D. M., Jimenez, B. A., Mims, P. J., Knight, V. F., Spooner, F., Lee, A., \& Flowers, C. (2012). The effects of a "tell-show-try-apply" professional development package on teachers of students with severe developmental disabilities. Teacher Education and Special Education: The Journal of the Teacher Education Division of the Council for Exceptional Children, 35, 212-227.

Bulgren, J. A., Sampson Graner, P., \& Deshler, D. D. (2013). Literacy challenges and opportunities for students with learning disabilities in social studies and history. Learning Disabilities Research \& Practice, $28,17-27$.

Campbell, T., Zuwallack, R., Longhurst, M., Shelton, B. E., \& Wolf, P. G. (2014). An examination of the changes in science teaching orientations and technology-enhanced tools for student learning in the context of professional development. International Journal of Science Education, 36(11), 1815-1848.

Common Core State Standards. (2010). Washington, DC: National Governors Association Center for Best Practices, Council of Chief State School Officers. Available at http://www.corestandards.org/ 
Cortiella, C., \& Horowitz, S. H. (2014). The state of learning disabilities: Facts, trends and emerging issues. New York: National Center for Learning Disabilities.

Desimone, L. M. (2009). Improving impact studies of teachers' professional development: Toward better conceptualizations and measures. Educational Researcher, 38(3), 181-199.

Diamond, B. S., Maerten-Rivera, J., Rohrer, R. E., \& Lee, O. (2014). Effectiveness of a curricular and professional development intervention at improving elementary teachers' science content knowledge and student achievement outcomes: Year 1 results. Journal of Research in Science Teaching, 51(5), 635658.

Ertmer, P. A., Ottenbreit-Leftwich, A. T., Sadik, O., Sendurur, E., \& Sendurur, P. (2012). Teacher beliefs and technology integration practices: A critical relationship. Computers \& Education, 59, 423-435.

Ferretti, R. P., \& Okolo, C. M. (1996). Authenticity in learning: Multimedia design projects in the social studies for students with disabilities. Journal of Learning Disabilities, 29(5), 450-460.

Gearhart, M., \& Wolf, S. A. (1994). Engaging teachers in assessment of their students' narrative writing: The role of subject matter knowledge. Assessing Writing, 1, 67-90.

Gersten, R. (1998). Recent advances in instructional research for students with learning disabilities. Learning Disabilities Practice, 13(3), 162-170.

Gersten, R., \& Baker, S. (2001). Teaching expressive writing to students with learning disabilities: A metaanalysis. Elementary School Journal, 101, 251-272.

Gersten, R., Compton, D., Connor, C. M., Dimino, J., Santoro, L., Linan-Thompson, S., \& Tilly, W. D. (2008). Assisting students struggling with reading: Response to intervention and multi-tier intervention for reading in the primary grades. A practice guide. (NCEE 2009-4045). Washington, DC: National Center for Education Evaluation and Regional Assistance, Institute of Education Sciences, U.S. Department of Education.

Gersten, R., Fuchs, L. S., Williams, J. P., \& Baker, S. (2001). Teaching reading comprehension strategies to students with learning disabilities: A review of research. Review of Educational Research, 71(2), $279-320$.

Greenleaf, C., Schoenbach, R., Cziko, C., \& Mueller, F. (2001). Apprenticing adolescent readers to academic literacy. Harvard Educational Review, 71(1), 79-129.

Guinee, K. (2004, October 19-23). Internet searching by K-12 students: A research-based process model. Paper presented at the Association for Educational Communications and Technology, Chicago, IL.

Guskey, T. R. (2000). Evaluating professional development. Thousand Oaks, CA: Corwin Press.

Ha, M., Baldwin, B. C., \& Nehm, R. H. (2015). The long-term impacts of short-term professional development: Science teachers and evolution. Evolution: Education and Outreach, 8(11), 1-23.

Haager, D., \& Vaughn, S. (2013). The Common Core State Standards and reading: Interpretations and implications for elementary students with learning disabilities. Learning Disabilities Research and Practice, 28, 5-16.

Harris, K. R., Graham, S., \& Adkins, M. (2015). Practice-based professional development and selfregulated strategy development for tier 2, at-risk writers in second grade. Contemporary Educational Psychology, 40, 5-16.

Johnson, C. C., \& Fargo, J. D. (2010). Urban school reform enabled by transformative professional development: Impact on teacher change and student learning of science. Urban Education, 45, 4-29.

Jones, A. C., Scanlon, E., \& Clough, G. (2013). Mobile learning: Two case studies of supporting inquiry learning in informal and semiformal settings. Computers \& Education, 61, 21-32.

Knox, C., Anderson-Inman, L., Terrazas-Arellanes, F. E., Walden, E., \& Hildreth, B. (2015). The SOAR strategies for online academic research: Helping middle school students meet new standards. In Y. 
Rosen (Ed.), Handbook of research on technology tools for real-world skill development. Hershey, PA: IGI Global.

Leu, D. J., Jr. (2000). Developing new literacies: Using the Internet in content area instruction. In M. McLaughlin \& M. Vogt (Eds.), Creativity and innovation in content area teaching (pp. 183-206). Norwood, MA: Christopher-Gordon.

Leu, D. J., Jr. (2002). The new literacies: Research on reading instruction with the Internet and other digital technologies. In J. Samuels \& A. E. Farstrup (Eds.), What research has to say about reading instruction (pp. 310-336). Newark, DE: International Reading Association.

Leu, D. J., Jr. (2011). New literacies_-Enriching research and theory. In P. J. Dunston, L. B. Gambrell, K. Headley, S. K. Fullerton, P. M. Stecker, V. R. Gillis, \& C. C. Bates (Eds.), 60th Yearbook of the Literacy Research Association. Newark, DE: International Reading Association.

Leu, D. J., Forzani, E., Burlingame, C., Kulikowich, J., Sedransk, N., Coiro, J., \& Kennedy, C. (2013). The new literacies of online research and comprehension: Assessing and preparing students for the $21^{\text {st }}$ century with Common Core State Standards. In S. B. Neuman \& L. B. Gambrell (Eds.), Quality reading instruction in the age of Common Core State Standards. Newark, DE: International Reading Association.

Leu, D. J., \& Kinzer, C. K. (2000). The convergence of literacy instruction with networked technologies for information, communication, and education. Reading Research Quarterly, 35(1), 108-127.

Levin, D., \& Arafeh, S. (2002). The digital disconnect the widening gap between internet-savvy students and their schools. Washington, DC: Pew Internet \& American Life Project.

Little, J. W. (1993). Teachers' professional development in a climate of educational reform. Educational Evaluation and Policy Analysis, 15(2), 129-151.

Little, J. W. (1999). Organizing schools for teacher learning. In L. Darling-Hammond \& G. Sykes (Eds.), Teaching as the learning profession: Handbook of teaching and policy. San Francisco, CA: JosseyBass.

Little, J. W. (2002). Locating learning in teachers' communities of practice: Opening up problems of analysis in records of everyday work. Teaching and Teacher Education, 18(8), 917-946.

Lumpe, A., Czerniak, C., Haney, J., \& Beltyukova, S. (2011). Beliefs about teaching science: The relationship between elementary teachers' participation in professional development and student achievement. International Journal of Science Education, 34, 153-166.

Mathews, L., Holt, C., \& Arrambide, M. (2014). Factors influencing the establishment and sustainability of professional learning communities: The teacher's perspective. International Journal of Business and Social Science, 5(11), 23-29.

McLaughlin, M. W., \& Talbert, J. E. (1993). How the world of students and teachers challenges policy coherence. In S. H. Fuhrman (Ed.), Designing coherent education policy: Improving the system. San Francisco, CA: Jossey-Bass.

Nadelson, L. S., Callahan, J., Pyke, P., Hay, A., Dance, M., \& Pfiester, J. (2013). Teacher STEM perception and preparation: Inquiry-based STEM professional development for elementary teachers. The Journal of Educational Research, 106(2), 157-168.

National Center for Education Statistics (NCES). (2015). 2015 Mathematics \& Reading Assessments. Retrieved from http://www.nationsreportcard.gov/reading_math_2015/\#? grade $=4$

Office of Educational Technology. (2010). Transforming American education: Learning powered by technology. Washington, DC: U.S. Department of Education.

Pancsofar, N., \& Petroff, J. G. (2013). Professional development experiences in co-teaching: Assocations with teacher confidence, interests, and attitudes. Teacher Education and Special Education, 36(2), 8396. 
Parette, H. P., Hourcade, J. J., Blum, C., Watts, E. H., Stoner, J. B., Wojcik, B. W., \& Chrismore, S. B. (2013). Technology user groups and early childhood education: A preliminary study. Early Childhood Education Journal, 41(3), 171-179.

Penuel, W. R., Bates, L., Gallagher, L. P., Pasnik, S., Llorente, C., Townsend, E., Hupert, N., Dominguez, X., \& VanderBorght, M. (2012). Supplementing literacy instruction with a media-rich intervention: Results of a randomized controlled trial. Early Childhood Research Quarterly, 27, 115-127.

Penuel, W. R., Fishman, B. J., Yamaguchi, R., \& Gallagher, L. P. (2007). What makes professional development effective? Strategies that foster curriculum implementation. American Educational Research Journal, 44(4), 921-958.

Ritzhaupt, A. D., Dawson, K., \& Cavanaugh, C. (2012). An investigation of factors influencing student use of technology in K-12 classrooms using path analysis. Journal of Educational Computing Research, 46, 229-254.

Robinson, J., Myran, S., Strauss, R., \& Reed, W. (2014). The impact of an alternative professional development model on teacher practices in formative assessment and student learning. Teacher Development: An International Journal of Teachers' Professional Development, 18, 141-162.

Rosenberg, M. (2012, May 21). Beyond competence: It's the journey to mastery that counts. Retrieved December 9, 2015 from http://www.learningsolutionsmag.com/articles/930/beyond-competence-its-thejourney-to-mastery-that-counts

Sadik, A. (2008). Digital storytelling: A meaningful technology-integrated approach for engaged student learning. Educational Technology Research and Development, 56, 487-506.

Schifter, D., \& Fosnot, C. T. (1993). Reconstructing mathematics education: Stories of teachers meeting the challenges of reform. New York, NY: Teachers College Press.

Stein, M. K., Smith, M. S., \& Silver, E. A. (1999). The development of professional developers: Learning to assist teachers in new settings in new ways. Harvard Educational Review, 69, 237-269.

Swanson, H. L. (2001). Searching for the best model for instructing students with learning disabilities. Focus on Exceptional Children, 34, 1-15.

U.S. Department of Education. (2010). Building the Legacy: IDEA 2004. Washington, DC: U.S. Department of Education.

Vaughn, S., Gersten, R., \& Chard, D. J. (2000). The underlying message in LD intervention research: Findings from research syntheses. Exceptional Children, 67, 99-114.

Walker, A., Recker, M., Ye, L., Brooke Robertshaw, M., Sellers, L., \& Leary, H. (2012). Comparing technology-related teacher professional development designs: A multilevel study of teacher and student impacts. Educational Technology Research and Development, 60, 421-444.

Wasik, B. A., \& Hindman, A. H. (2011). Improving vocabulary and pre-literacy skills of at-risk preschoolers through teacher professional development. Journal of Educational Psychology, 103, 455-469.

Yin, Y., Tomita, M. K., \& Shavelson, R. J. (2014). Using formal embedded formative assessments aligned with a short-term learning progression to promote conceptual change and achievement in science. International Journal of Science Education, 36(4), 531-552. 


\section{Appendix A: \\ Guinee Research Process Map}

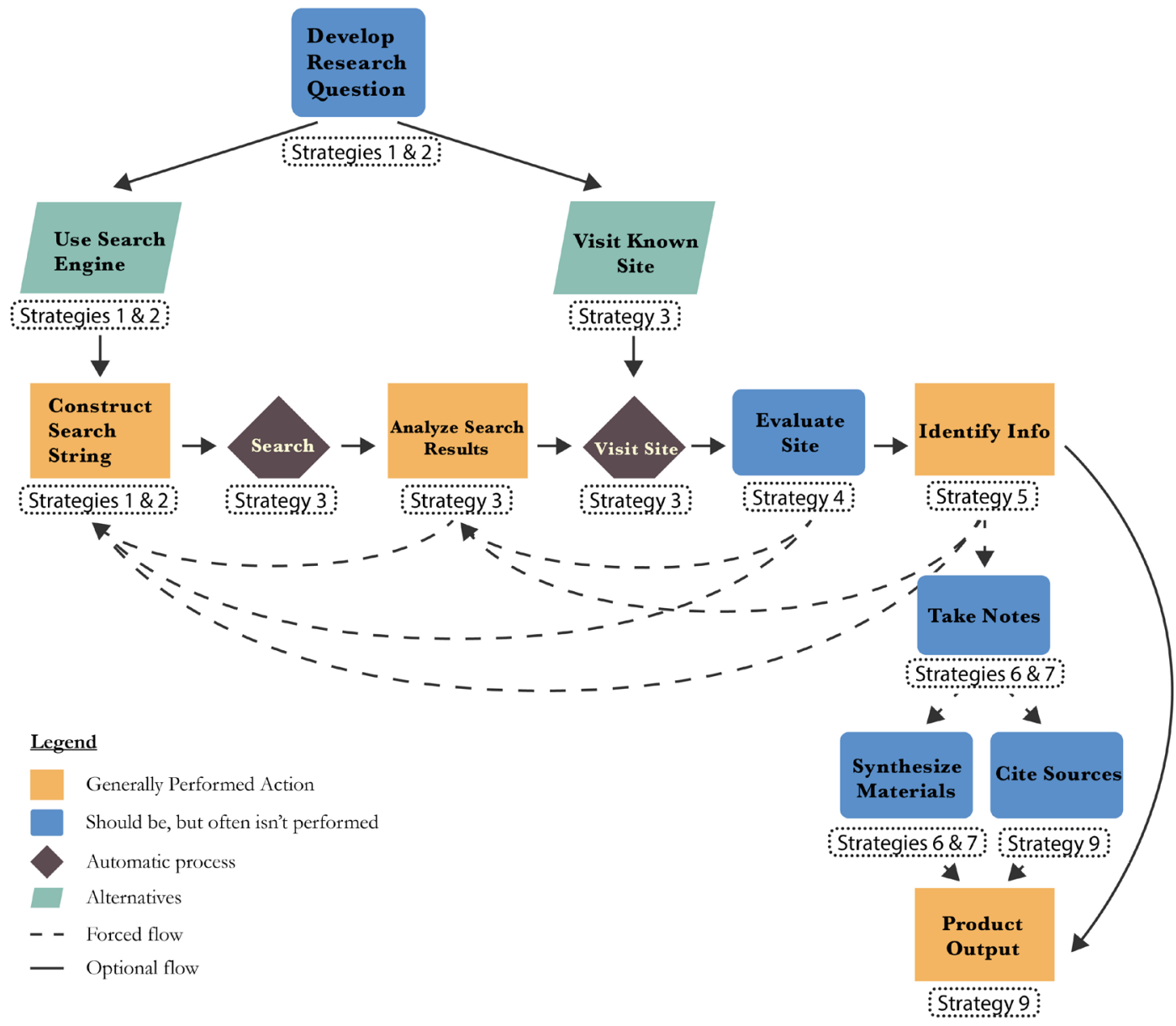




\section{Appendix B: \\ Example of a Completed Digital Notebook}

Research Question: How much homework should students be expected to do each night? Digital Notebook

http://www.nea.org/tools/16938.htm (A)

The National PTA recommendations fall in line with general guidelines suggested by researcher Harris Cooper: 10-20 minutes per night in the first grade, and an additional 10 minutes per grade level thereafter. $(A)$

Experts advise schools or districts to include teachers, parents, and students in any effort to set homework policies. (A)

http://www.ncbi.nlm.nih.gov/pubmed/22906052 (B)

This longitudinal study examined how nightly variations in adolescents' study and sleep time are associated with academic problems on the following day. Participants $(N=535$, 9th grade $M($ age $)$ $=14.88$ ) completed daily diaries every day for 14 days in 9th, 10th, and 12th grades. Results suggest that regardless of how much a student generally studies each day, if that student sacrifices sleep time to study more than usual, he or she will have more trouble understanding material taught in class and be more likely to struggle on an assignment or test the following day. (B)

http://sleepfoundation.org/sleep-topics/teens-and-sleep (C)

Teens need about 8 to 10 hours of sleep each night to function best. Most teens do not get enough sleep - one study found that only $15 \%$ reported sleeping $81 / 2$ hours on school nights. (C)

Not getting enough sleep or having sleep difficulties can: Limit your ability to learn, listen, concentrate and solve problems. Make you more prone to pimples. Lead to aggressive or inappropriate behavior. (C)

http://files.eric.ed.gov/fulltext/ED536245.pdf (D)

According to a national survey of 2,900 randomly selected American children conducted by researchers at the University of Michigan (Hofferth \& Sandberg, 2000), the amount of time spent on homework increased from 1 hour and 53 minutes per week in 1981 to 2 hours and 16 minutes per week in 1997. (D)

Skaggs (2007) examined NAEP reading scores and found that fourth grade students who spent over one hour per night on homework and students who did not complete any homework received the same average reading score. In math, students who reported spending one-half hour on homework scored about the same as students who completed no homework. (D)

http://news.stanford.edu/news/2014/march/too-much-homework-031014.html (E)

The researchers used survey data to examine perceptions about homework, student well-being and behavioral engagement in a sample of 4,317 students from 10 high-performing high schools in upper-middle-class California communities. Students in these schools average about 3.1 hours of homework each night. (E)

The study found that too much homework is associated with: greater stress, reductions in health, less time for friends, family and extracurricular pursuits (E)

In places where students attend high-performing schools, too much homework can reduce their time to foster skills in the area of personal responsibility (E) 


\section{Outline}

Introduction: Students are being assigned more homework than in the past. Some students think they have too much homework. Parents, teachers, and experts are trying to decide how much homework students should do each night.

\section{Students today have to do more homework, but that doesn't always help them learn more}

time spent on homework increased from 1 hour and 53 minutes per week in 1981 to 2 hours and 16 minutes per week in 1997. (D)

students who spent over one hour per night on homework and students who did not complete any homework received the same average reading score. In math, students who reported spending one-half hour on homework scored about the same as students who completed no homework. (D)

too much homework can reduce students' time to foster skills in the area of personal responsibility $(\mathrm{E})$

2. Too much homework takes away sleep time and lead to health problems

if that student sacrifices sleep time to study more than usual, he or she will have more trouble understanding material taught in class (B)

Most teens do not get enough sleep — one study found that only 15\% reported sleeping $81 / 2$ hours on school nights. (C)

Not getting enough sleep or having sleep difficulties can: Limit your ability to learn, listen, concentrate and solve problems. Make you more prone to pimples. Lead to aggressive or inappropriate behavior. (C)

One study found that too much homework is associated with: greater stress and reductions in health $(E)$

\section{Homework should take 10 minutes or less per night per grade}

10-20 minutes per night in the first grade, and an additional 10 minutes per grade level thereafter. (A)

Experts advise schools or districts to include teachers, parents, and students in any effort to set homework policies. (A)

Conclusion: Too much homework may do more harm than good. Students should be expected to do no more than 10 minutes of homework per night per grade, and they should have a say in how much homework they do.

\section{Resources}

http://www.nea.org/tools/16938.htm (A)

http://www.ncbi.nlm.nih.gov/pubmed/22906052 (B)

http://sleepfoundation.org/sleep-topics/teens-and-sleep (C)

http://files.eric.ed.gov/fulltext/ED536245.pdf (D)

http://news.stanford.edu/news/2014/march/too-much-homework-031014.html (E) 


\begin{tabular}{|c|c|c|c|c|}
\hline & Novice $(<43 \%)$ & $\begin{array}{c}\text { Competent (43\%- } \\
62 \%)\end{array}$ & $\begin{array}{c}\text { Experienced (62\%- } \\
90 \%)\end{array}$ & Master $(90+\%)$ \\
\hline \multirow[t]{2}{*}{$\begin{array}{l}\text { Strategy } \\
\text { 1: Start }\end{array}$} & $\begin{array}{l}\text { Less than } 3 \text { different } \\
\text { URLs found. } \\
\qquad \text { Score }=0\end{array}$ & \multicolumn{3}{|c|}{ At least 3 different URLs found. } \\
\hline & $\begin{array}{l}\text { Less than } 3 \text { different } \\
\text { websites found. } \\
\text { Score }=0\end{array}$ & \multicolumn{3}{|c|}{ At least 3 different websites found. } \\
\hline $\begin{array}{c}\text { Strategy } \\
\text { 2: Improve }\end{array}$ & $\begin{array}{l}\text { No URL is workable. } \\
\text { Score }=0\end{array}$ & $\begin{array}{l}\text { One URL is workable. } \\
\qquad \text { Score }=1\end{array}$ & \multicolumn{2}{|c|}{ Two or more URLs are workable. } \\
\hline $\begin{array}{l}\text { Strategy } \\
\text { 3: Choose }\end{array}$ & $\begin{array}{l}\text { No URL directly links } \\
\text { to a relevant topic (or } \\
\text { no article was cit- } \\
\text { ed/linked). } \\
\qquad \text { Score = } 0\end{array}$ & $\begin{array}{l}\text { One URL directly links to } \\
\text { a relevant topic. } \\
\qquad \text { Score }=1\end{array}$ & \multicolumn{2}{|c|}{$\begin{array}{l}\text { Two or more URLs directly link to a relevant topic. } \\
\text { Score = 2 }\end{array}$} \\
\hline $\begin{array}{l}\text { Strategy } \\
\text { 4: Weigh- } \\
\text { ing }\end{array}$ & $\begin{array}{l}\text { No URL is from credi- } \\
\text { ble, reliable, current } \\
\text { source (.edu, .org, } \\
\text {.gov, famous names } \\
\text { such as Smithsonian, } \\
\text { CNN). } \\
\text { Score = } 0\end{array}$ & $\begin{array}{l}\text { One URL is from a cred- } \\
\text { ible, reliable, current } \\
\text { source (.edu, .org, .gov, } \\
\text { famous names such as } \\
\text { Smithsonian, CNN). } \\
\text { Score }=1\end{array}$ & \multicolumn{2}{|c|}{$\begin{array}{l}\text { Two or more URLs are from credible, reliable, current } \\
\text { sources (.edu, .org, .gov, famous names such as } \\
\text { Smithsonian, CNN). } \\
\text { Score = } 2\end{array}$} \\
\hline $\begin{array}{l}\text { Strategy } \\
\text { 5: Finding }\end{array}$ & $\begin{array}{l}\text { No evidence (facts, } \\
\text { statistics, quantifiable } \\
\text { data, quote, cop- } \\
\text { ied/pasted clippings) } \\
\text { that information was } \\
\text { gathered. } \\
\qquad \text { Score }=0\end{array}$ & \multicolumn{2}{|c|}{$\begin{array}{l}\text { Some evidence (At least } 1 \text { fact, statistic, quantifiable } \\
\text { datum, quote, copied/pasted clipping) that information } \\
\text { was gathered. }\end{array}$} & $\begin{array}{l}\text { Good evidence (2 or more } \\
\text { facts, statistics, quantifiable } \\
\text { data, quotes, cop- } \\
\text { ied/pasted clippings) that } \\
\text { information was gathered. } \\
\text { Score = 1 }\end{array}$ \\
\hline $\begin{array}{l}\text { Strategy } \\
\text { 6: Read }\end{array}$ & $\begin{array}{l}\text { Insufficient evidence } \\
\text { to lead to conclusions } \\
\text { about the topic be- } \\
\text { cause of very little } \\
\text { information (only } 1-2 \\
\text { facts) or irrelevant } \\
\text { information. } \\
\qquad \text { Score }=0\end{array}$ & \multicolumn{2}{|c|}{$\begin{array}{l}\text { Difficult to draw conclusions about the topic because } \\
\text { the information gathered is somewhat limited in quali- } \\
\text { ty and/or quantity. }\end{array}$} & $\begin{array}{l}\text { The information gathered is } \\
\text { clearly relevant and would } \\
\text { support conclusions about } \\
\text { the topic. }\end{array}$ \\
\hline
\end{tabular}




\begin{tabular}{|c|c|c|c|c|}
\hline & Novice $(<43 \%)$ & $\begin{array}{l}\text { Competent (43\%- } \\
62 \%)\end{array}$ & $\begin{array}{l}\text { Experienced (62\%- } \\
90 \%)\end{array}$ & Master $(90+\%)$ \\
\hline $\begin{array}{l}\text { Strategy } \\
\text { 7: Record }\end{array}$ & $\begin{array}{l}\text { No URLs or notes are } \\
\text { tagged. } \\
\qquad \text { Score }=0\end{array}$ & \multicolumn{2}{|c|}{ One or 2 URLs and notes are tagged. } & $\begin{array}{l}\text { At least } 3 \text { URLs and all } \\
\text { notes are tagged. } \\
\qquad \text { Score = } 2\end{array}$ \\
\hline $\begin{array}{l}\text { Strategy } \\
\text { 8: Catego- } \\
\text { ries }\end{array}$ & $\begin{array}{l}\text { The information is not } \\
\text { organized in anything } \\
\text { that resembles an } \\
\text { outline. }\end{array}$ & $\begin{array}{l}\text { The information is orga- } \\
\text { nized by URL or by ar- } \\
\text { gument (yes/no, } \\
\text { pro/con), but not in an } \\
\text { outline. }\end{array}$ & $\begin{array}{l}\text { The information is orga- } \\
\text { nized in a way that re- } \\
\text { sembles an outline, but } \\
\text { the introduction or con- } \\
\text { clusion is missing and/or } \\
\text { the category headings } \\
\text { are incomplete or insuffi- } \\
\text { cient (less than } 3 \text { head- } \\
\text { ings). } \\
\text { Score = } 2\end{array}$ & $\begin{array}{l}\text { The information resembles } \\
\text { an outline based on rele- } \\
\text { vant topics, with at least } 3 \\
\text { good headings. }\end{array}$ \\
\hline \multirow[t]{2}{*}{$\begin{array}{l}\text { Strategy } \\
\text { 9: Com- } \\
\text { bine }\end{array}$} & $\begin{array}{l}\text { Sources are not cor- } \\
\text { rectly cited in any way } \\
\text { (for example, all link } \\
\text { to a generic website } \\
\text { like npr.org or an error } \\
\text { page). } \\
\text { Score = } 0\end{array}$ & $\begin{array}{l}\text { Sources are present, but } \\
\text { some or all are not in a } \\
\text { section or they do not } \\
\text { have tags AND only } 1 \text { is } \\
\text { a good source that suc- } \\
\text { cessfully links to a rele- } \\
\text { vant article. } \\
\qquad \text { Score }=1\end{array}$ & $\begin{array}{l}\text { Sources are present, but } \\
\text { some or all are not in a } \\
\text { section or they do not } \\
\text { have tags AND } 2 \text { or } \\
\text { more are good sources } \\
\text { that successfully link to } \\
\text { relevant articles. } \\
\qquad \text { Score = } 2\end{array}$ & $\begin{array}{l}\text { Sources are correctly cited } \\
\text { and relevant, function, and } \\
\text { are in a separate section } \\
\text { with tags. }\end{array}$ \\
\hline & $\begin{array}{l}\text { The research gath- } \\
\text { ered is limited in } \\
\text { quantity and/or quality } \\
\text { and/or lacks organiza- } \\
\text { tion and does not } \\
\text { meet expectations. } \\
\text { Score = } 0\end{array}$ & \multicolumn{2}{|c|}{$\begin{array}{l}\text { The quality and quantity of the research gathered } \\
\text { meets expectations and the information is organized. }\end{array}$} & $\begin{array}{l}\text { The quality and quantity of } \\
\text { the research gathered and } \\
\text { level of its organization } \\
\text { exceeds expectations } \\
\text { (tagged and referenced } \\
\text { correctly, with relevant } \\
\text { topics). } \\
\text { Score = } 2\end{array}$ \\
\hline Total $\rightarrow$ & $0 / 21=0 \%$ & $10.5 / 21=50 \%$ & $15.5 / 21=74 \%$ & $21 / 21=100 \%$ \\
\hline
\end{tabular}




\begin{tabular}{|c|c|c|}
\hline & Question & $\begin{array}{l}\text { My } \\
\text { Score }\end{array}$ \\
\hline \multirow[t]{2}{*}{$\begin{array}{l}\text { Strategy } \\
\text { 1: Start }\end{array}$} & 1. Did I find at least 3 different URLs? & \\
\hline & 2. Did I find at least 3 different websites? & \\
\hline $\begin{array}{c}\text { Strategy } \\
\text { 2: Improve }\end{array}$ & $\begin{aligned} \text { No URL works } & =0 \\
\text { One URL works } & =1 \\
\text { Two or more URLs work } & =2\end{aligned}$ & \\
\hline $\begin{array}{l}\text { Strategy } \\
\text { 3: Choose }\end{array}$ & $\begin{array}{l}\text { 4. Do my URLs directly link to a relevant topic? } \\
\qquad \begin{array}{r}\text { No URL directly links to a relevant topic (or no article was cited) }=0 \\
\text { One URL directly links to a relevant topic }=1 \\
\text { Two or more URLs directly link to a relevant topic }=2\end{array}\end{array}$ & \\
\hline $\begin{array}{l}\text { Strategy } \\
\text { 4: Weigh- } \\
\text { ing }\end{array}$ & $\begin{array}{l}\text { 5. Are my URLs from credible, reliable, current sources (.edu, } \\
\text { org, .gov, famous names such as Smithsonian, CNN - not wiki or } \\
\text { debate sites)? } \\
\qquad \begin{array}{r}\text { No URL is from a reliable source }=0 \\
\text { One URL is from a reliable source }=1 \\
\text { Two or more URLs are from reliable sources }=2\end{array}\end{array}$ & \\
\hline $\begin{array}{l}\text { Strategy } \\
\text { 5: Finding }\end{array}$ & $\begin{array}{l}\text { 6. Do I have evidence (facts, statistics, quantifiable data, quote, } \\
\text { copied-and-pasted clippings) that I gathered information? } \\
\qquad \begin{array}{r}\text { No fact, statistic, quantifiable datum, quote, clipping }=0 \\
\text { At least } 1 \text { fact, statistic, quantifiable datum, quote, clipping }=.5 \\
2 \text { or more facts, statistics, quantifiable data, quotes, clippings }=1\end{array}\end{array}$ & \\
\hline $\begin{array}{l}\text { Strategy } \\
\text { 6: Read }\end{array}$ & $\begin{array}{l}\text { 7. Do I have enough information to make conclusions about my } \\
\text { topic? } \\
\begin{array}{r}\text { Can not draw conclusions because I have only } 1-2 \text { facts or irrelevant information }=0 \\
\text { Hard to draw conclusions because of limited information }=1 \\
\text { My information is relevant and supports conclusions }=2\end{array}\end{array}$ & \\
\hline
\end{tabular}




\begin{tabular}{|c|c|c|}
\hline & Question & $\begin{array}{c}\text { My } \\
\text { Score }\end{array}$ \\
\hline $\begin{array}{l}\text { Strategy } \\
\text { 7: Record }\end{array}$ & $\begin{array}{l}\text { 8. Did I tag my URLs and notes? } \\
\qquad \begin{array}{r}\text { No URLs or notes are tagged }=0 \\
\text { One or } 2 \text { URLs and notes are tagged }=1 \\
\text { At least } 3 \text { URLs and all notes are tagged }=2\end{array}\end{array}$ & \\
\hline $\begin{array}{l}\text { Strategy } \\
\text { 8: Catego- } \\
\text { ries }\end{array}$ & $\begin{array}{l}\text { 9. Did I organize my information in an outline? } \\
\text { The information is not organized }=0 \\
\text { The information is organized by URL or argument (yes/no, pro/con) }=1 \\
\text { The information is in an outline with less than } 3 \text { headings }=2 \\
\text { The information is in an outline with at least } 3 \text { good headings }=3\end{array}$ & \\
\hline $\begin{array}{l}\text { Strategy } \\
\text { 9: Com- } \\
\text { bine }\end{array}$ & $\begin{array}{l}\text { 10. Did I cite my sources correctly? } \\
\text { Sources are not cited }=0 \\
\text { Sources are cited, but not all in a section or tagged, and only } 1 \text { is relevant }=1 \\
\text { Sources are cited, but not all in a section or tagged, and only } 2 \text { are relevant }=2 \\
\text { Sources are correctly cited and relevant, and are in a section with tags }=3\end{array}$ & \\
\hline & $\begin{array}{l}\text { 11. What is the quality of my research and organization? } \\
\qquad \begin{array}{r}\text { The research is low quality and unorganized }=0 \\
\text { The research is medium quality and information is organized }=1\end{array} \\
\text { The research is high quality and organized with relevant topics, references, and tags = } \\
2\end{array}$ & \\
\hline
\end{tabular}




\section{Appendix E:}

Alignment of Strategies and Common Core State
Standards for English Language Arts

\begin{tabular}{|c|c|c|c|}
\hline $\begin{array}{l}\text { Strate- } \\
\text { gy }\end{array}$ & CCSS & $\begin{array}{c}\text { Common Core State Standards } \\
\text { Content }\end{array}$ & $\begin{array}{c}\text { Alignment of SOAR Strategies and Com- } \\
\text { mon Core State Standards }\end{array}$ \\
\hline $\begin{array}{l}\text { All } \\
\text { Strate- } \\
\text { gies }\end{array}$ & $\begin{array}{l}\text { CCSS.E } \\
\text { LA- } \\
\text { Literacy. } \\
\text { WHST.6 } \\
-8.7 .\end{array}$ & $\begin{array}{l}\text { Conduct short research projects to } \\
\text { answer a question (including a self- } \\
\text { generated question), drawing on } \\
\text { several sources and generating addi- } \\
\text { tional related, focused questions that } \\
\text { allow for multiple avenues of explora- } \\
\text { tion. }\end{array}$ & $\begin{array}{l}\text { Throughout the nine SOAR Strategies, stu- } \\
\text { dents conduct a short research project to an- } \\
\text { swer a question they have created about that } \\
\text { topic. Students use several website sources, } \\
\text { gather information, and organize that infor- } \\
\text { mation into a coherent outline, based on their } \\
\text { exploration. }\end{array}$ \\
\hline $\begin{array}{l}\text { 1: Start- } \\
\text { ing a } \\
\text { Web } \\
\text { Search }\end{array}$ & $\begin{array}{l}\text { CCSS.E } \\
\text { LA- } \\
\text { Literacy. } \\
\text { WHST.6 } \\
-8.2 . \mathrm{B}\end{array}$ & $\begin{array}{l}\text { Develop the topic with relevant, well- } \\
\text { chosen facts, definitions, concrete } \\
\text { details, quotations, or other infor- } \\
\text { mation and examples. }\end{array}$ & $\begin{array}{l}\text { Students generate relevant research ques- } \\
\text { tions (based on details, facts, and definitions) } \\
\text { and use them to find information on a specific } \\
\text { topic. Based on results in later strategies, stu- } \\
\text { dents revise/create new relevant research } \\
\text { questions based on facts, definitions, concrete } \\
\text { details, quotations, and other information and } \\
\text { examples acquired from their searches. }\end{array}$ \\
\hline $\begin{array}{l}\text { 2: Im- } \\
\text { proving } \\
\text { a Web } \\
\text { Search }\end{array}$ & $\begin{array}{l}\text { CCSS.E } \\
\text { LA- } \\
\text { Literacy. } \\
\text { WHST.6 } \\
-8.9\end{array}$ & $\begin{array}{l}\text { Draw evidence from informational } \\
\text { texts to support analysis, reflection, } \\
\text { and research. }\end{array}$ & $\begin{array}{l}\text { After reading results, students determine if } \\
\text { their sites are relevant to their research ques- } \\
\text { tions and will support analysis, reflection, and } \\
\text { research on the topic. If not, students reflect } \\
\text { on the questions, using what they learned } \\
\text { from the search to gather/construct specific } \\
\text { words/phrases for better questions. }\end{array}$ \\
\hline $\begin{array}{l}\text { 3: } \\
\text { Choos- } \\
\text { ing } \\
\text { Three } \\
\text { Good } \\
\text { Sites to } \\
\text { Open }\end{array}$ & $\begin{array}{l}\text { CCSS.E } \\
\text { LA- } \\
\text { Literacy. } \\
\text { RH.6- } \\
8.8\end{array}$ & $\begin{array}{l}\text { Distinguish among fact, opinion, and } \\
\text { reasoned judgment in a text. }\end{array}$ & $\begin{array}{l}\text { In deciding what sites to use, students distin- } \\
\text { guish between biased and unbiased sites, } \\
\text { examining facts, opinions, and reasoned } \\
\text { judgments. Students search for famous name } \\
\text { and non-commercial (.edu, .gov, and .org) } \\
\text { sites. }\end{array}$ \\
\hline $\begin{array}{c}4: \\
\text { Weigh- } \\
\text { ing a } \\
\text { Website }\end{array}$ & $\begin{array}{l}\text { CCSS.E } \\
\text { LA- } \\
\text { Literacy. } \\
\text { WHST.6 } \\
-8.8\end{array}$ & $\begin{array}{l}\text { Gather relevant information from } \\
\text { multiple print and digital sources, } \\
\text { using search terms effectively; as- } \\
\text { sess the credibility and accuracy of } \\
\text { each source; and quote or para- } \\
\text { phrase the data and conclusions of } \\
\text { others while avoiding plagiarism and } \\
\text { following a standard format for cita- } \\
\text { tion. }\end{array}$ & $\begin{array}{l}\text { After using search terms to find relevant sites, } \\
\text { students review the sites. Students gather } \\
\text { data about the sites, deciding if they are trust- } \\
\text { worthy, finding the sponsors, determining why } \\
\text { the site was created, and deciding its ease of } \\
\text { use, to determine the credibility and accuracy } \\
\text { of each site. Later, students will continue to } \\
\text { quote/paraphrase data from these sources in } \\
\text { order to avoid plagiarism (Strategy 7) and pre- } \\
\text { sent citations in a reference list (Strategy 9). }\end{array}$ \\
\hline $\begin{array}{l}\text { 5: Find- } \\
\text { ing } \\
\text { for- } \\
\text { mation } \\
\text { in a } \\
\text { Website }\end{array}$ & $\begin{array}{l}\text { CCSS.E } \\
\text { LA- } \\
\text { Literacy. } \\
\text { RH.6- } \\
8.2\end{array}$ & $\begin{array}{l}\text { Determine the central ideas or infor- } \\
\text { mation of a primary or secondary } \\
\text { source; provide an accurate sum- } \\
\text { mary of the source distinct from prior } \\
\text { knowledge or opinions. }\end{array}$ & $\begin{array}{l}\text { Students search for key words in a website, } \\
\text { and then read sections where that key word } \\
\text { appears to determine the section's relevancy } \\
\text { for the topic. As students continue research- } \\
\text { ing, they record notes from these relevant sec- } \\
\text { tions (Strategy } 7 \text { ). }\end{array}$ \\
\hline
\end{tabular}




\begin{tabular}{|c|c|c|c|}
\hline $\begin{array}{l}\text { Strate- } \\
\text { gy }\end{array}$ & ccss & $\begin{array}{c}\text { Common Core State Standards } \\
\text { Content }\end{array}$ & $\begin{array}{c}\text { Alignment of SOAR Strategies and Com- } \\
\text { mon Core State Standards }\end{array}$ \\
\hline $\begin{array}{l}\text { 6: } \\
\text { Reading } \\
\text { Online }\end{array}$ & $\begin{array}{l}\text { CCSS.E } \\
\text { LA- } \\
\text { Literacy. } \\
\text { RI.6.4 }\end{array}$ & $\begin{array}{l}\text { Determine the meaning of words and } \\
\text { phrases as they are used in a text, } \\
\text { including figurative, connotative, and } \\
\text { technical meanings. }\end{array}$ & $\begin{array}{l}\text { By learning the text-to-speech strategy, stu- } \\
\text { dents use technology to listen to words, } \\
\text { phrases, or text sections, to hear the word for } \\
\text { recognition, pronunciation, and understanding. }\end{array}$ \\
\hline $\begin{array}{l}\text { 7: Rec- } \\
\text { ord } \\
\text { Notes }\end{array}$ & $\begin{array}{l}\text { CCSS.E } \\
\text { LA- } \\
\text { Literacy. } \\
\text { W.6-8.9 }\end{array}$ & $\begin{array}{l}\text { Draw evidence from literary or infor- } \\
\text { mational texts to support analysis, } \\
\text { reflection, and research. }\end{array}$ & $\begin{array}{l}\text { Students copy URLs and relevant text into } \\
\text { their digital notebooks, determining how the } \\
\text { text will support their analysis, reflection, and } \\
\text { research on their topic. }\end{array}$ \\
\hline $\begin{array}{l}\text { 8: Cre- } \\
\text { ating } \\
\text { Catego- } \\
\text { ries }\end{array}$ & $\begin{array}{l}\text { CCSS.E } \\
\text { LA- } \\
\text { Literacy. } \\
\text { WHST.6 } \\
-8.2 A\end{array}$ & $\begin{array}{l}\text { Introduce a topic clearly, previewing } \\
\text { what is to follow; organize ideas, } \\
\text { concepts, and information into } \\
\text { broader categories as appropriate to } \\
\text { achieving purpose; include format- } \\
\text { ting (e.g., headings), graphics (e.g., } \\
\text { charts, tables), and multimedia when } \\
\text { useful to aiding comprehension. }\end{array}$ & $\begin{array}{l}\text { After taking notes, students create an outline. } \\
\text { The outline includes an introduction and con- } \\
\text { clusion, and students create relevant topics. } \\
\text { The outline is formatted so that information } \\
\text { (including graphics and multimedia if appro- } \\
\text { priate) can be inserted (Strategy 9). }\end{array}$ \\
\hline $\begin{array}{l}\text { 9: Com- } \\
\text { bine } \\
\text { Notes in } \\
\text { an Out- } \\
\text { line }\end{array}$ & $\begin{array}{l}\text { CCSS.E } \\
\text { LA- } \\
\text { Literacy. } \\
\text { RI. } 6.7\end{array}$ & $\begin{array}{l}\text { Integrate information presented in } \\
\text { different media or formats (e.g., vis- } \\
\text { ually, quantitatively) as well as in } \\
\text { words to develop a coherent under- } \\
\text { standing of a topic or issue. }\end{array}$ & $\begin{array}{l}\text { In their outline, students integrate the research } \\
\text { they have gathered (including URLs and text } \\
\text { selections) under their topic headings to cre- } \\
\text { ate a coherent understanding of the topic. }\end{array}$ \\
\hline
\end{tabular}




\section{Appendix F: \\ SOAR Instructional Planning Matrix}

\begin{tabular}{|c|c|c|c|c|}
\hline Strategy & Skills Students Learn & Time & Teaching Strategy & Formative Assessment \\
\hline $\begin{array}{l}\text { 1: Starting } \\
\text { a Web } \\
\text { Search }\end{array}$ & & & & \\
\hline $\begin{array}{l}\text { 2: Improv- } \\
\text { ing a Web } \\
\text { Search }\end{array}$ & & & & \\
\hline $\begin{array}{l}\text { 3: Choosing } \\
\text { Three Good } \\
\text { Sites to } \\
\text { Open }\end{array}$ & & & & \\
\hline $\begin{array}{l}\text { 4: Weighing } \\
\text { a Website }\end{array}$ & & & & \\
\hline $\begin{array}{l}\text { 5: Finding } \\
\text { Information } \\
\text { in a Web- } \\
\text { site }\end{array}$ & & & & \\
\hline $\begin{array}{l}\text { 6: Reading } \\
\text { Online }\end{array}$ & & & & \\
\hline $\begin{array}{l}\text { 7: Record } \\
\text { Notes }\end{array}$ & & & & \\
\hline $\begin{array}{l}\text { 8: Creating } \\
\text { Categories }\end{array}$ & & & & \\
\hline $\begin{array}{l}\text { 9: Combine } \\
\text { Notes in an } \\
\text { Outline }\end{array}$ & & & & \\
\hline
\end{tabular}




\section{Biographies}

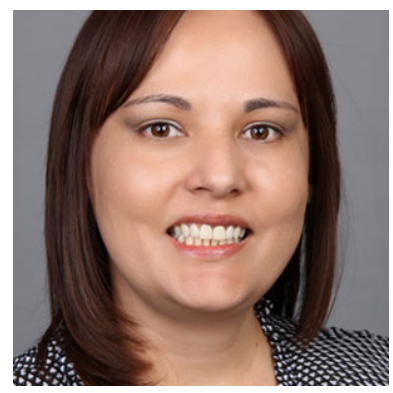

Fatima E. Terrazas-Arellanes, Ph.D., is a Research Assistant Professor at the University of Oregon College of Education in Eugene, Oregon, and a former teacher in Mexico. She is the Principal Investigator of Project ESCOLAR to support science learning for students with learning disabilities and Project S-SOAR to develop professional development models to support teaching strategies for conducting research online. She was a Co-Principal Investigator of Project COPELLS to develop and evaluate bilingual, collaborative, multimedia online science modules for middle school English learners. Her areas of expertise include literacy and bi-literacy instruction for Spanish-speaking English learners, use of assistive technology to address the educational needs of students with learning disabilities, and research design and analysis of qualitative and quantitative data.

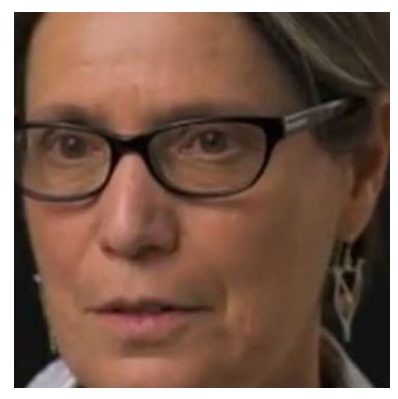

Carolyn Knox, Ph.D., is the former Assistant Director at the Center for Advanced Technology in Education at the University of Oregon College of Education in Eugene, Oregon, and has conducted research and development projects for more than 25 years that create and promote innovative uses of technology in the classroom and evidencebased strategies for struggling learners. She was the Principal Investigator of several projects to develop and evaluate Web-based curricula to teach science and academic online research to middle school students.

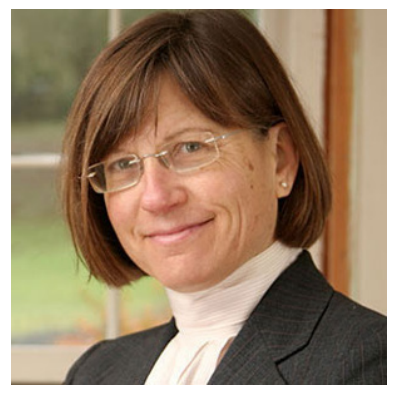

Lisa A. Strycker, M.A., is a research methodologist at the University of Oregon College of Education in Eugene, Oregon. She has more than 25 years of experience in the social sciences. Her research interests include primary and secondary education, Internet-delivered interventions, youth physical activity, adolescent substance use, chronic illness management, worksite health, and specialized analytical techniques for multiple-group, multilevel, and longitudinal data.

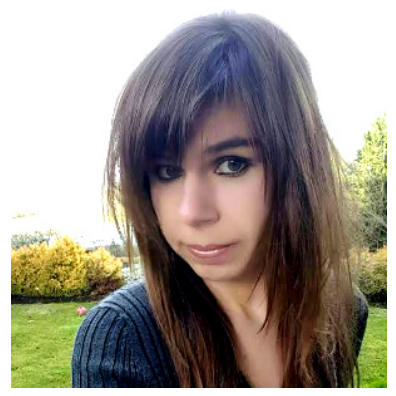

Emily Walden, M.A., is a Research Assistant at the University of Oregon College of Education in Eugene, Oregon. She completed a bachelor's degree in English and psychology at the University of Oregon in 2010 and a master's degree in developmental psychology at the University of Oregon in 2011. Her research with federally funded projects (COPELLS, S-SOAR, and ESCOLAR) primarily involves improving education outcomes, especially in science, for middle school students with learning disabilities and English learners through the use of technology. 